\title{
PRODUCTIVE, NUTRITIONAL, AND PHYSIOLOGICAL RESPONSES OF BARKI EWES TO DIFFERENT TYPES OF ROUGHAGES (BERSEEM HAY, ATRIPLEX OR SILAGE) AND DRY YEAST DURING GESTATION AND SUCKLING PERIODS
}

\author{
Khalid Zein-Alabdein Kewan \\ Department of Animal and Poultry Nutrition, Desert Research Center, 11753, Al-Mattaria, Cairo, Egypt \\ Email: kewandrc@yahoo.com; (D) ORCID: 0000-0003-0122-5642 \\ supporting Information
}

\section{ABSTRACT}

The aim of study was to investigate the effect of different types of roughage (hay, green and silage) and yeast added to the barley grain on the productive performance of the Barki ewes during the gestation and suckling periods. Eighty-four Barki ewes, 3-4 years of age and $42.93 \pm 0.19 \mathrm{~kg}$ of average body weight, were randomly assigned to six groups (14 ewes in each) before the mating season. A factorial design was used for $3 \times 2$ treatments based on Berseem hay (BH), and either fresh Atriplex halimus (FA) or silage (AS) in the absence $\left(Y_{-}\right)$or presence $\left(\mathrm{Y}^{+}\right)$of $5 \mathrm{~g} / \mathrm{ewe} /$ day of the dry yeast. All ewe groups recorded gain in their live body weight (LBW) during early and late gestation period. The highest loss in LBW was recorded for $\mathrm{BH}$ and $\mathrm{Y}^{+}$during the suckling period. The AS was the highest consumed roughage followed by $\mathrm{BH}$ and then FA during the gestation and suckling periods. The addition of yeast $\left(\mathrm{Y}^{+}\right)$resulted a reduction of roughage intake than control one $\left(\mathrm{Y}^{-}\right)$ during both gestation stages but the total milk yield (TMY) was significantly higher for BH followed by FA and AS. Also, $Y^{+}$significantly increased $(P<0.05)$ the TMY $(423)$ compared to $Y^{-}(384)$ treatment. Milk fat content was not affected by roughages type, yeast addition or their interaction. However, milk protein content was significantly higher for $\mathrm{BH}(5.14 \%)$ than the other types of roughage. Silage (AS) was better than other roughages in conversion efficiency to milk and also $\mathrm{Y}^{+}$was better than $\mathrm{Y}$. Yeast addition to ewes diets increased birth weight of their lambs compared to un-supplemented one ( $\mathrm{Y}$ ). It could be concluded that weaning weight relative to that in hay group was $93.6 \%$ and $80.4 \%$ for AS and FA, respectively. Generally, adding yeast to different roughage diets during suckling period led to a significant increase in weaning weight. Furthermore, the economic efficiency $(\mathrm{EE})$ was higher $(\mathrm{P}<0.05)$ in both FA and AS compared to BH. Also, yeast addition $\left(\mathrm{Y}^{+}\right)$resulted in higher $E E(P<0.05)$ in compared to $\mathrm{Y}^{\text {. }}$

Keywords: Atriplex, Barki ewes, Lamb, Silage, Yeast.

Abbreviations: BH: Berseem hay; FA: fresh Atriplex halimus; AS: Atriplex silage; $\mathrm{Y}^{+}$: dry yeast addition; $\mathrm{Y}$ : without yeast. TMY: The total milk yield; LBW: live body weight; DM: dry matter; TDN: total digestible nutrients; DCP: digestible crude protein.

\section{INTRODUCTION}

In Egypt, barley (Hordeum vulgare) is grown as a main crop in the North Western Coastal Region (NWCR) in about 63000 ha under rain-fed condition and in about 55000 ha in the Nile Valley under irrigation system (Kewan et al., 2009). Barley is mainly used either in the grain form as an energy supplement or straw as a roughage part of animal diets (Bonavia and McGregor, 2021).

The range vegetation is considered the basic source of ruminants feed in NWCR. Atriplex species are common fodder plants in the arid and semi-arid regions (Alhanafi et al., 2019). Because of its tolerance to drought and salinity conditions, they grow in saline soil or irrigated with saline water, and can play an important role in livestock feeding (Ben Salem et al., 2010). Atriplex species could provide green biomass during the drought season and maintain a relatively moderate crude protein (CP, ranging 10.3-25.2\% of dry matter content) throughout the year albeit having low energy content (Ben Salem et al., 2010). In general, Atriplex is characterized by high mineral concentration but digestible ether extract and soluble carbohydrates are low (Ben Salem et al., 2002). Deficiency of available carbohydrates and the rapid fermentation of the saltbushes $\mathrm{CP}$ in the rumen may be responsible for the poor utilization of their protein as judged from the large losses of nitrogen in urine (Ben Salem et al., 2010). They reported that feeding on Atriplex solely adversely affects the general condition of sheep and goats with more pronounced effect on sheep. Coordination between the level of dietary readily available carbohydrates and ruminal-nitrogen is suggested to maximize the utilization of dietary nitrogen by micro- organisms (El Shaer and Gihad, 1994). Barley grains as energy supplement was suggested to stimulate saltbush intake and to correct the loss of ruminal ammonia (Shawket, 1999b). In the NWCR of Egypt, Bedouin grow rainy fed 
barley, which successfully used as a supplementary feed for livestock grazing the native rangelands in these areas (Shawket, 1999a). Ensiling process improves halophytes acceptability and consequently increases both of intake and of digestibility by ruminants. These results are of great importance towards making best use of available unpalatable desert shrubs as animal feeds specially for desert sheep and goats (Kewan et al., 2019). Various dietary additives, dry yeast (Saccharomyces cerevisiae) in particular, are widely used in ruminant diets modulate rumen metabolism, which ultimately improves nutrient use and animal performance (Shurson 2018 and Maamouri and Ben Salem, 2021). Enhancing feed quality and utilization by using certain feed additives may be considered a partial vertical solution to the problem of negative feed balance of total digestible nutrients (TDN) and digestible crude protein (DCP) which stated for a long period in the animal production sector of Egypt (Kewan et al., 2021b).

Nutrition during maternal and suckling periods is potential means of improving farm profitability and ewe lifetime performance. Therefore, this experiment was conducted to evaluate the effect of different types of roughage (hay, green and silage) and yeast added to the barley grain on the productive performance of the Barki ewes during the gestation and suckling periods. The investigated responses of ewes to roughage forms and yeast addition were as follows: ewe Body weighty, body-weight changes, feed intake and feed conversion ratio, milk production, nitrogen and water metabolism, rumen fermentation, Blood biochemical composition, performance of suckling lambs.

\section{MATERIALS AND METHODS}

Ethical approval

All processes of the study were in according to animal welfare rules and approved by DRC ethical committee.

\section{Animals and management}

The current experiment was conducting in Maryout Research Station, Desert Research Center during the year 2018. A total number of eighty-four Barki ewes, aging about 2-4 years and with average body weight of $42.93 \pm 0.19 \mathrm{~kg}$ were chosen from ewes flock before the mating season. Ewes were randomly assigned to six groups (fourteen ewes in each) in a $3 \times 2$ factorial design to examine effects of different forage types and yeast addition on ewes body weight changes during gestation and suckling periods, milk production and their offspring performance. The experimental period represents the reproductive and productive cycle of the ewe i.e., mating, gestation and suckling periods. Six fertile Barki rams were used for mating; one of each ewe-group. Rams were allowed to rotate among different ewes groups to avoid ram/group confounding effect. The mating period lasted for 35 days (nearly two estrous cycles) after which the rams were separated from the ewes. Estrous was detected by means of colored grease on the ram brisket. Ewes were checked daily as defined by marking with the ram and the service was then recorded. Colors used were changed weekly. Ewes were weighted before joining and at biweekly intervals thereafter.

\section{Diets and feeding}

The experimental groups of animals were housed and fed separately in six pens and each treatment was fed in group. Crushed barley grains was used as concentrate supplement for all ewes throughout the experiment. The barley grains was offered daily in equal two meals (09:00 AM and 14:00 PM) to cover 75\% of total energy requirements of ewes based on their physiological stage (Kearl, 1982). Berseem (Trifolium Alexandrinum) hay (BH), and Atriplex halimmus as fresh (FA) or silage (AS) forms were offered ad-lib to cover the remaining requirements of the ewes according to their physiological condition. Dry yeast (Saccharomyces cerevisae; $10^{9} \mathrm{cfu} / \mathrm{g}$ ) was used as a feed additive to investigate its effect on the utilization of forages. The investigational diets were as follows:

1) Barley grains without yeast addition + $\mathrm{BH}$ ad lib, (Diet BHY).

2) Barley grains supplemented with 5 g yeast/head/day $+\mathrm{BH}$ ad lib, (Diet $\left.B H Y^{+}\right)$.

3) Barley grains without yeast addition + fresh Atriplex (FA) ad lib, (Diet FAY-).

4) Barley grains supplemented with $5 \mathrm{~g}$ yeast/head/day + fresh Atriplex (FA) ad lib, (Diet FAY').

5) Barley grains without yeast addition+ Atriplex silage (AS) ad lib, (Diet ASY).

6) Barley grains supplemented with $5 \mathrm{~g}$ yeast/head/day + Atriplex silage (AS) ad lib, (Diet ASY+).

Ewes had free access to fresh water and salt block with mineral and trace elements. At days 76, 130 and 205 days of the experiment, 5 ewes of each group (with their offspring in case of 205d) were moved to separate pens and fed individually according to their feeding regimen to determine actual feed intake in the physiological stages; early and late gestation as well as the suckling periods.

\section{Silage preparation and assessing the quality}

Leaves and succulent stems of fresh Atriplex halimus (saltbush) was collected and chopped at 2-3 cm length, then ensiled with adding molasses at rate of five percent (on DM basis). Ensiled materials were filled in special places $(3 \times 2 \times 2$ $\mathrm{m}$, each), stocked by trampling and finally covered with a plastic sheet and a $30 \mathrm{~cm}$ layer of sand to ensure anaerobic fermentation for at least one month before using for feeding the experimental animals. For determination of silage quality, $50 \mathrm{gm}$ of wet silage was extracted in a blender with $100 \mathrm{ml}$ of distilled water for 10 minutes. The homogenate was filtrated through four layers of chess cloth. The filtrate was used for measuring $\mathrm{PH}$, ammonia-nitrogen $\left(\mathrm{NH}_{3}-\mathrm{N}\right)$ and total volatile fatty acids (VFAs) concentrations. 


\section{Milk yield estimation}

The total milk yield (TMY) was estimated biweekly (six records) excluding the first week after parturition. After separation the lambs from their dams, 5 ewes from each group were milked to empty the mammary gland and milked again after $6 \mathrm{~h}$ to access milk yield at a $6 \mathrm{~h}$ and the amount resulted was assumed the normal rate of milk secretion and was extrapolated at $24 \mathrm{~h}$ to estimate daily milk yield. An individual $100 \mathrm{ml}$ milk sample was taken and preserved with 0.5 $\mathrm{ml}$ potassium dichromate solution $(70 \mathrm{mg} / \mathrm{L})$ then frozen at $-20{ }^{\circ} \mathrm{C}$ until individually analyzed.

\section{Performance of lambs}

The born lambs were ear tagged and their body weight was recorded within 24 hours after parturition and at two weeks intervals thereafter till weaning at 90 days of age. Thus, the growth performance (average daily gain; ADG) of growing lambs was calculated.

\section{Digestibility, nitrogen balance and water metabolism trials}

After weaning the lambs, digestibility trials were conducted by using 4 ewes (averaged $40.87 \mathrm{~kg} \pm 0.49$ SE of body weight) randomly selected from each group to evaluate the digestibility of nutrients, feeding values, and water intake was determined as well. Animals were moved to separate metabolic cages and fed individually according their feeding regimens for 15 days as an adaptation period followed by 7 days for collecting feces, urine and recording actual feed and water intake. Soft water was available for free choice during the experimental period. Total feces and urine were recorded daily and representative samples of about $10 \%$ were taken daily. At the end of the collection period, composited feces samples of each animal were mixed, dried and ground for sampling. Samples of feed offered, refused and feces were taken and stored for chemical analysis.

\section{Rumen fermentation}

On day 22 of the digestibility trial, rumen fluid samples were collected at $3 \mathrm{~h}$ after morning feeding using a stomach tube and strained through four-layers of cheesecloth. Ruminal $\mathrm{pH}$ was immediately determined using a handheld $\mathrm{pH}$ meter. Then, $20 \mathrm{~mL}$ of the rumen fluid was acidified with $0.4 \mathrm{~mL}$ of $50 \%$ (vol/vol) sulfuric acid and stored at $-20^{\circ} \mathrm{C}$ for later analysis.

\section{In situ evaluation of rations}

Four rumen fistulated Barki rams were used to conduct the in situ OM disappearance (ISOM\%) of the total mixed rations which was previously prepared by mixing $B G$ and roughage according to their actual intake, then $5 g$ ( 2 replicates/ram) was incubated in the rumen for $24 \mathrm{~h}$. Microbial protein (MCP) synthesized in the rumen was calculated depending upon ruminally digested $\mathrm{OM}$ along with some published figures and assumptions that was illustrated previously by Kewan (2013).

\section{Blood indices}

Blood samples were collected from the jugular vein at the end of the digestibility trials at time $0 \mathrm{~h}$ post-feeding. Blood was collected into clean test tubes with anticoagulant (EDTA). Blood samples were centrifuged at $\mathbf{3 0 0 0} \mathrm{rpm}$ for 20 minutes to obtain plasma that were frozen at $-20^{\circ} \mathrm{C}$ for late biochemical assay. Plasma concentrations of Glucose (glu), total proteins (TP), albumin (Alb), Urea, Creatinine (Cr) and Creatinine clearance (CC) were assessed calorimetrically using commercial chemical reagent kits (Bio-diagnostic product Kit, Egypt).

\section{Chemical analysis}

The official methods of AOAC (2005) were used for the determination of dry matter (DM), crude protein (CP) ether extract (EE) crude fiber (CF) and nitrogen free extract (NFE) in feeds, refusal if any and fecal samples. Milk samples were analyzed for total solids (TS), protein, fat and ash using the methods of (AOAC, 1984). The rumen fluid samples were analyzed for ammonia-nitrogen $\left(\mathrm{NH}_{3}-\mathrm{N}\right)$ and total volatile fatty acids (TVFA) according to Preston (1995) and AOAC (1997), respectively.

\section{Calculations and statistical analysis}

Energy corrected milk (ECM) was calculated using the formula of Bernard (1997):

$\operatorname{ECM}(\mathrm{kg})=(0.3246 \times$ milk yield $)+(12.86 \times$ fat yield $)+(7.04 \times$ protein yield $)$.

Milk energy value (MEV) was calculated according to Baldi et al. (1992):

MEV $(\mathrm{kcal} / \mathrm{kg})=203.8+(8.36 \times$ fat $\%)+(6.29 \times \mathrm{CP} \%)$.

Creatinine clearance, $\mathrm{ml} / \mathrm{min}=(\mathrm{mg} \mathrm{Cr}$ per dl urine $\times \mathrm{ml}$ urine per $24 \mathrm{hr}) /(\mathrm{mg} \mathrm{Cr}$ per dl plasma $\times 1440)$

Because of Barki ewe, consider as mutton ewe so milk conversion efficiency (MCE) was calculated assuming suckling milk (SMY) equals total milk yield (TMY) as reported by Morag (1973).

$M C E=T M Y / A D G$

The data of present experiment were statistically analyzed by two-way analysis of variance using the General Linear Model Procedure of the SAS software (SAS, 2002). The model used is: $Y i j=\mu+T i+C j+(T C) i j+e i j k$ 
where $\mathrm{Yijk}=$ individual observation; $\boldsymbol{\mu}=$ the overall mean; $\mathrm{Ti}=$ the fixed effect of forage type; $\mathrm{C} \mathbf{j}=$ the fixed effect of yeast addition; (TC)ij= the interaction between the two factors and eijk = random error. Tukey's range test was used to compare differences among treatments.

\section{RESULTS AND DISCUSSION}

\section{Chemical composition}

The chemical composition of feed ingredients and characteristics of Atriplex silage are presented in Table 1. The data indicated that Atriplex as fresh forage had lower dry matter (DM) content (23.82\%) compared to that of silage forage or Berseem hay (39.29 and 78.14\%, respectively). Silage forage had lower CP, CF, ash and NDF but higher OM, NFE and cellulose than fresh forage. Berseem hay had higher CP and ADF but lower hemicellulose content than Atriplex hay or silage. In this regard, BH is considered as high quality forage while Atriplex halimus is considered as poor quality forage.

The high level of ash in Atriplex (21.62\%) may decrease the ME content of to be low as relative to that of Berseem hay (Ben Salem et al., 2002), otherwise may force the animals to consume much water with consequential influences on rumen functions (Shawket et al., 2015). Protein content of Atriplex was somewhat high (14.92\%) but does not fully account for their nutritive value as protein supplements, where about $66 \%$ of total $\mathrm{N}$ in Atriplex was soluble and degradable in the rumen as reported by Ben Salem et al. (2002). The present values of cell wall content of Atriplex foliage are around the range of that reported in other fodder shrubs by Ben Salem et al. (2010) which was 30-45\% for NDF, 15$29 \%$ for ADF and 6-14\% for ADL. Barley grain is highly starch feed (Khattab 2007) so its NFE content is $75.31 \%$. The values of chemical composition of FA, AS and BG in this study are nearly similar to those obtained by Abd El-Rahman et al. (2004) and Shawket et al. (2015). The proximate composition of the bakery's yeast biomass (Saccharomyces cerevisiae) presented in Table 1 is characterized by high content of protein (42.28\%) and ash (7.99\%). The CF content was low being value $0.51 \%$. Total carbohydrates (49.02\%) represent nearly half of the dry biomass. The present results agree with those recently reported by Kewan et al. (2021b), which were 45.72, 6.79, 2.51, 45.72\% for CP, ash, CF and NFE, respectively. The fermentative characteristics of the ensiled Atriplex (Table 1) indicated that $\mathrm{pH}$ value, $\mathrm{NH}_{3}-\mathrm{N}$ and TVFA concentrations were in acceptable values for good quality silage and were comparable with that found by Shawket et al. (2015) and de Araújo et al. (2018).

\section{Table 1 - Chemical composition of feeds and characteristics of Atriplex silage}

\begin{tabular}{|c|c|c|c|c|c|}
\hline Item & BH & FA & AS & BG & Yeast \\
\hline DM\% & 78.14 & 23.82 & 39.29 & 87.50 & 91.00 \\
\hline \multicolumn{6}{|c|}{ Nutrients \% based on DM basis: } \\
\hline OM & 85.54 & 78.38 & 80.76 & 96.05 & 92.01 \\
\hline Ash & 14.46 & 21.62 & 19.24 & 3.95 & 7.99 \\
\hline CP & 16.10 & 14.92 & 13.28 & 9.94 & 42.28 \\
\hline CF & 25.34 & 23.32 & 19.18 & 7.31 & 0.51 \\
\hline $\mathrm{EE}$ & 2.06 & 1.71 & 1.72 & 3.49 & 0.20 \\
\hline NFE & 42.04 & 38.43 & 46.58 & 75.31 & 49.02 \\
\hline NDF & 49.64 & 48.27 & 41.16 & 26.26 & - \\
\hline ADF & 43.16 & 32.88 & 30.79 & 6.26 & - \\
\hline ADL & 10.04 & 11.76 & 10.43 & 4.17 & - \\
\hline Hemi-cellulose & 6.48 & 15.39 & 10.37 & 20.00 & - \\
\hline Cellulose & 33.12 & 21.12 & 20.36 & 2.09 & - \\
\hline \multicolumn{6}{|l|}{ Characteristics of silage: } \\
\hline $\mathrm{pH}$ & - & - & $4.59 \pm 0.10$ & - & - \\
\hline TVFA, meq/100 g & - & - & $14.27 \pm 1.04$ & - & - \\
\hline $\mathrm{NH}_{3}-\mathrm{N}, \mathrm{mg} / 100 \mathrm{~g}$ & - & - & $4.05 \pm 0.18$ & - & - \\
\hline
\end{tabular}

\section{Body weight changes of ewes}

Body weight changes of ewes at starting of the experiment, at 90 and 150 days of gestation and suckling stage are presented in Table 1. The LBW of ewes increased to the maximum just before lambing (at 150 days of pregnancy) and sharply decreased (post-lambing) to the minimum at 90 days post-lambing (weaning) in all groups. Concerning the effect of the treatment, results revealed significant differences among groups in LBW of ewes at 150 days of gestation owing to the type of roughages intake being the highest value recorded for AS group but $\mathrm{BH}$ was the lowest. In contrast with the present findings, EL-Gohary et al. (2017) showed insignificant influence of feeding tanniniferous plants shrubs (Atriplex, Acacia and Cassava) as alternatives to BH on LBW of Barki ewes. The same direction obtained by EL-Saadany et al. 
(2016) who recorded insignificant differences among different experimental groups (Acacia, Atriplex and Cassava vs. Berseem hay) in LBW of Barki ewes during the 15 days pre-partum, at lambing and at 60 days post-partum.

Supplementation with dry yeast (Table 2) had positive effect $(P<0.05)$ on ewes body weight at 90 and $150 \mathrm{~d}$ of gestation as compared to the un-supplemented one, however no significant effects were observed at 2 and $90 \mathrm{~d}$ post lambing. In this concern, Shawket et al. (2015) found had no significant effect on the LBW of ewes at weaning; 45.09, 44.04 and $44.60 \mathrm{~kg}$ for dams received control, fresh and silage diets, respectively. Furthermore, Abdel-Gawad (2012) found that LBW of Rahmani ewes was not significantly affected at 150 days of pregnancy or 60d post-lambing as a result of using Lacture dried yeast at levels of 1 or $2 \mathrm{~g} / \mathrm{head} / \mathrm{d}$.

Also, the interaction between roughage types and yeast addition (Table 2) follows the same significant pattern of yeast effect being $\mathrm{AS}^{+}$group showed the highest $(\mathrm{P}<0.05)$ value compared to the other groups. In addition, the results may indicate that both treatments ( $R$ and $Y$ ) and their interaction did not affect nutrient requirements of ewes at 2 up to 90d post-lambing as their LBW was similar (Table 2).

Body weight gain (Table 2) was revealed during the early and late gestation periods. The highest values recorded in the early gestation period belonged to $\mathrm{BH}(2.76 \mathrm{~kg}), \mathrm{Y}^{+}(2.97 \mathrm{~kg})$ and $\mathrm{ASY}^{+}(3.45 \mathrm{~kg})$ groups within $\mathrm{R}, \mathrm{Y}$ and $\mathrm{R}^{\star} \mathrm{Y}$ treatments, respectively. However, the highest values recorded in the last gestation period were for AS $(7.31 \mathrm{~kg}), \mathrm{Y}^{+}(7.30$ $\mathrm{kg})$ and $\mathrm{ASY}^{+}(8.30 \mathrm{~kg})$ groups within $\mathrm{R}, \mathrm{Y}$ and $\mathrm{R}^{*} \mathrm{Y}$ treatments, respectively. It is of interest that body weight increased during the early stages of pregnancy, which may refers to the poor body condition score of ewes at the start of experimentation. In addition, the differences in weight gain at late gestation stage may be attributed to litter size of ewes in each group. On the other hand, body weight loss (Table 2) was revealed at 2 days post-lambing mainly due to losing placenta and embryonic membranes as well as lamb were born. It is of interest that AS, $\mathrm{Y}^{+}$and $\mathrm{ASY}^{+}$showed the highest loss value $(6.56,6.32$ and $7.30 \mathrm{~kg}$, respectively) within $R, Y$ and $R * Y$ treatments, respectively. The present result were lower than that reported by Shawket et al. (2015) who recorded 13.60, 10.86 and $10.02 \mathrm{~kg}$ weight loss in ewes fed control,_Atriplex+Acacia either fresh or silage, respectively.

Nevertheless, high milk production by ewes and/ or high barley consumption by offspring at 2 months of age may cause high loss in ewe LBW as observed in $\mathrm{BH}(2.54 \mathrm{~kg})$ and $\mathrm{Y}^{+}(2.59 \mathrm{~kg})$ within $\mathrm{R}$ and $\mathrm{Y}$ treatments, respectively (Table 2), but for the interaction treatments, the $\mathrm{BHY}^{+}(2.81 \mathrm{~kg})$ and $\mathrm{FAY}^{+}(2.70 \mathrm{~kg})$ were higher than the other treatment groups. These findings were in accordance with results reported by Shawket et al. (2015) who found Barki_ewes fed control, fresh and silage foilage lost $6.14,4.54$ and $2.95 \mathrm{~kg}$, respectively throughout 16 weeks as suckling period. However, Ben Salem et al. (2010) attributed the loss of the body weight of sheep fed Atriplex to its low contents of energy and true protein otherwise high salt and oxalates.

Table 2 - Ewes body weight changes during different periods of gestation and suckling stages

\begin{tabular}{|c|c|c|c|c|c|c|c|c|c|c|c|}
\hline \multirow{2}{*}{\multicolumn{2}{|c|}{ Treatment }} & \multirow{2}{*}{$\begin{array}{l}\text { E- } \\
\text { No }\end{array}$} & \multicolumn{5}{|c|}{$\begin{array}{c}\text { Ewes body weight } \\
\text { (kg) }\end{array}$} & \multicolumn{2}{|c|}{$\begin{array}{c}\text { Body weight gain } \\
\text { (kg) }\end{array}$} & \multicolumn{2}{|c|}{$\begin{array}{c}\text { Body weight loss } \\
\text { (kg) }\end{array}$} \\
\hline & & & Od & 90d-G & 150d-G & 2d-PL & 90d-PL & 90d-G & 150d-G & PL & SP \\
\hline \multirow{3}{*}{$\mathbf{R}$} & $\mathrm{BH}$ & 28 & $42.75^{a}$ & $45.51^{a}$ & $49.41^{b}$ & $43.75^{a}$ & $41.21^{a}$ & $2.76^{a}$ & $6.66^{c}$ & $5.66^{b}$ & $2.54^{a}$ \\
\hline & FA & 28 & $42.89^{a}$ & $45.40^{a}$ & $49.70^{a b}$ & $44.12^{a}$ & $41.83^{a}$ & $2.51^{c}$ & $6.81^{b}$ & $5.58^{b}$ & $2.29^{b}$ \\
\hline & AS & 28 & $43.15^{a}$ & $45.82^{a}$ & $50.46^{a}$ & $43.89^{a}$ & 41.71a & $2.67^{b}$ & $7.31^{a}$ & $6.57^{a}$ & $2.18^{b}$ \\
\hline \multirow{2}{*}{$\mathbf{Y}$} & $\mathbf{Y}^{-}$ & 42 & $42.81^{a}$ & $45.14^{b}$ & $49.37^{b}$ & $43.81^{a}$ & $41.72^{a}$ & $2.33^{b}$ & $6.56^{b}$ & $5.56^{b}$ & $2.09^{b}$ \\
\hline & $\mathrm{Y}^{+}$ & 42 & $43.05^{a}$ & $46.02^{a}$ & $50.35^{a}$ & $44.03^{a}$ & $41.44 a$ & $2.97^{a}$ & $7.30^{a}$ & $6.32^{a}$ & $2.59^{a}$ \\
\hline \multirow{6}{*}{$\mathbf{R} * \mathbf{Y}$} & BHY- & 14 & $42.59^{a}$ & $45.21^{\mathrm{ab}}$ & $48.94^{b}$ & $43.60^{a}$ & $41.33^{a}$ & $2.62^{c}$ & $6.35^{\mathrm{e}}$ & $5.34 \mathrm{e}$ & $2.27^{b}$ \\
\hline & $\mathrm{BHY}^{+}$ & 14 & $42.91^{a}$ & $45.81^{\mathrm{ab}}$ & $49.88^{b}$ & $43.90^{a}$ & 41.09a & $2.90^{b}$ & $6.97^{b}$ & $5.98^{b}$ & $2.81^{a}$ \\
\hline & FAY- & 14 & $43.07^{a}$ & $45.03^{b}$ & $49.57^{b}$ & $44.07^{a}$ & $42.19^{a}$ & $1.96 \mathrm{e}$ & $6.50^{d}$ & 5.50 de & $1.88^{\mathrm{c}}$ \\
\hline & $\mathrm{FAY}^{+}$ & 14 & $43.23^{a}$ & $45.76^{a b}$ & $49.83^{b}$ & $44.17^{a}$ & $41.47^{a}$ & $2.53^{c}$ & $6.60^{d}$ & $5.66^{\mathrm{cd}}$ & $2.70^{a}$ \\
\hline & ASY- & 14 & $42.76^{a}$ & $45.17^{a b}$ & $49.59^{b}$ & $43.76^{a}$ & $41.64^{a}$ & $2.41^{d}$ & $6.83^{c}$ & $5.83^{\text {be }}$ & $2.12^{b}$ \\
\hline & $\mathrm{ASY}^{+}$ & 14 & $43.02^{a}$ & $46.47^{a}$ & $51.32^{a}$ & $44.02^{a}$ & $41.77^{a}$ & $3.45^{a}$ & $8.30^{a}$ & $7.30^{a}$ & $2.25^{b}$ \\
\hline
\end{tabular}

\section{Feed intake}

Data on barley and roughage intake by Barki ewes are presented in Table 3. Roughage type affect significantly $(P<0.05)$ on roughage intake (as DM basis or as a percent of total intake) during both gestation (early $90 \mathrm{~d}$ and late $60 \mathrm{~d}$ ) and suckling (90d) periods. Where AS was the highest consumed roughage followed by BH and then FA throughout the gestation and suckling periods. The lower intake of Atriplex (FA) compared to AS or BH was expected and can be attributed to its high salt and ADL contents (as shown in Table 1) that may have negative effects on palatability, digestion and rumen fill (Khattab, 2007, Fayed et al., 2010, Shawket et al., 2015 and Askar et al., 2016). On the other hand, higher intake of silage diet compared to fresh or hay diets may be attributed to better taste and palatability as well as lower content of secondary metabolites (Abu-Zanat and Tabbaa, 2003) and higher availability of nutrients as result of ensiling process (Khattab 2007). 
The addition of yeast $\left(\mathrm{Y}^{+}\right)$resulted in a reduction of roughages intake than control one ( $\left.\mathrm{Y}^{-}\right)$during both gestation stages but, they were comparable during suckling stage (Table 3). The reduction in roughage or total dry matter intake could be attributed to enhancing the nutritive value therefore the same amount of required nutrients become available in less quantity. This in contrast with results reported by Abou'I Ella (2007) and Abdel-Gawad (2012) where they found that total dry matter intake was significantly higher with addition of dried yeast to lactating ewe's rations. However, Ahmed et al. (2015) found no significant effect of yeast addition on feed intake for growing lambs fed $15 \%$ Atriplex $+15 \%$ Acacia $+70 \%$ concentrate mixture.

On the other hand, a significant $(\mathrm{P}<0.05)$ interaction was detected between roughage type and yeast addition regarding the DM of roughage intake (Table 3). The results of roughage intake showed ascending ranking values as ASY->

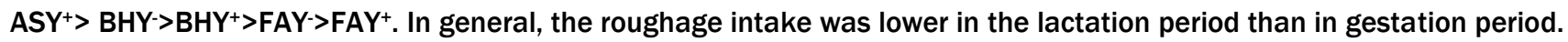

Silage roughage represented about $57.7-60.6 \%$ of the total food intake during pregnancy and lactation periods, respectively, which reduces the cost of the ration compared to $\mathrm{BH}$. It also covers the DM, energy and protein required during pregnancy and lactation to a better degree than fresh Atriplex forage.

Yeast addition reduced the total intake during pregnancy by $3.60-5.32 \%$ compared to that without yeast. Generally, variation in feed intake among groups reflects the feeding values of diets ingested. The present results of Atriplex intake are lower than that values reported by Abu-Zanat and Tabbaa (2006) who found that DM intakes of roughages (tibin or saltbush) averaged 0.63 and $0.70 \mathrm{~kg} \mathrm{DM} /$ ewe/day for 0 and $100 \%$ saltbush diets, respectively. They added that the percentages of roughages to total DMI varied from 44.1 to 51.2. Dry matter intakes relative to ewe BW averaged $2.5 \%$ and the suggested levels of DMI for ewes weighing 50-60 kg are between 3.0 and $3.4 \%$ in the last 4 weeks of gestation and between 3.8 and $4.2 \%$ in the first 6-8 weeks of lactation (NRC, 1985), which are well above the reported levels in our study.

Table 3 - Barley grain and roughages intake (g DM/head/d) by ewes during gestation and suckling periods

\begin{tabular}{|c|c|c|c|c|c|c|c|c|c|c|c|c|c|}
\hline \multirow{2}{*}{\multicolumn{2}{|c|}{ Treatment* }} & \multicolumn{3}{|c|}{ Early gestation } & \multirow{2}{*}{$\mathbf{R} \%$} & \multicolumn{3}{|c|}{ Late gestation } & \multirow{2}{*}{$\mathbf{R} \%$} & \multicolumn{3}{|c|}{ Suckling period } & \multirow{2}{*}{$\mathbf{R} \%$} \\
\hline & & BG & $\mathbf{R}$ & Total & & BG & $\mathbf{R}$ & Total & & BG & $\mathbf{R}$ & Total & \\
\hline \multirow{3}{*}{$\mathbf{R}$} & $\mathrm{BH}$ & $666^{a}$ & $762^{b}$ & $1428^{a}$ & 53.4 & $625^{a}$ & $680^{b}$ & $1305^{b}$ & 52.1 & $635^{c}$ & $655^{b}$ & $1290^{b}$ & 50.8 \\
\hline & FA & $596^{b}$ & $328^{c}$ & $924^{b}$ & 35.5 & $607^{b}$ & $459^{c}$ & $1066^{c}$ & 43.1 & $661^{b}$ & $507^{c}$ & $1168^{c}$ & 43.4 \\
\hline & AS & $565^{c}$ & $849^{a}$ & $1414^{a}$ & 60.0 & $601^{b}$ & $923^{a}$ & $1524^{a}$ & 60.6 & $672^{a}$ & $915^{a}$ & $1587^{a}$ & 57.7 \\
\hline \multirow{2}{*}{$\mathbf{Y}$} & $\mathbf{Y}$ & $603^{a}$ & $675^{a}$ & $1278^{a}$ & 52.8 & $612^{a}$ & $722^{a}$ & $1334^{a}$ & 54.1 & $649^{b}$ & $702^{a}$ & $1351^{a}$ & 52.0 \\
\hline & $\mathrm{Y}^{+}$ & $615^{a}$ & $617^{b}$ & $1232^{b}$ & 50.1 & $610^{a}$ & $653^{b}$ & $1263^{b}$ & 51.7 & $663^{a}$ & $684^{a}$ & $1347^{a}$ & 50.8 \\
\hline \multirow{6}{*}{$\mathbf{R} * \mathbf{Y}$} & BHY- & $661^{a}$ & $776^{b}$ & $1437^{a b}$ & 54.0 & $651^{a}$ & $750^{c}$ & $1401^{b}$ & 53.5 & $656^{b}$ & $692^{c}$ & $1348^{b}$ & 51.3 \\
\hline & $\mathrm{BHY}^{+}$ & $672^{a}$ & $747^{b}$ & $1419 \mathrm{ab}$ & 52.6 & $600^{b}$ & $611^{d}$ & $1211^{c}$ & 50.5 & $613^{d}$ & $618^{d}$ & $1231^{c}$ & 50.2 \\
\hline & FAY- & $570^{c}$ & $350^{c}$ & $920^{c}$ & 38.0 & $581^{b}$ & $441^{e}$ & $1022^{e}$ & 43.2 & $634^{c}$ & $477^{f}$ & $1111^{d}$ & 42.9 \\
\hline & $\mathrm{FAY}^{+}$ & $622^{b}$ & $306^{c}$ & $928^{c}$ & 33.0 & $632^{a}$ & $478^{e}$ & $1110^{d}$ & 43.1 & $688^{a}$ & $538^{e}$ & $1226^{c}$ & 43.9 \\
\hline & ASY- & $580^{c}$ & $899^{a}$ & $1479^{a}$ & 60.8 & $604^{b}$ & $974^{a}$ & $1578^{a}$ & 61.7 & $656^{b}$ & $936^{a}$ & $1592^{a}$ & 58.8 \\
\hline & $\mathrm{ASY}^{+}$ & $550^{c}$ & $799^{b}$ & $1349^{b}$ & 59.2 & $598^{b}$ & $871^{b}$ & $1469^{b}$ & 59.3 & $689^{a}$ & $895^{b}$ & $1584^{a}$ & 56.5 \\
\hline
\end{tabular}

\section{Contribution of roughage for ewe requirements}

Data in Table 4 show that AS contributed about $71.57 \%$ of the total DM requirement for ewes during early gestation and then decreased to 56.39 and $57.95 \%$ during the late gestation and the suckling periods, respectively (Table 4). The $\mathrm{BH}$ followed the same pattern but with lower values. However, FA contributes with almost similar values (from 27.86 to 31.98\%) during the three periods. The addition of yeast $\left(\mathrm{Y}^{+}\right)$contribute with lower percent of DM requirement than $\mathrm{Y}^{-}$, and in the same time both $Y^{-}$and $\mathrm{Y}^{+}$was higher in early gestation period than either the late gestation or the suckling period as shown in Table 4.

The interaction $(R * Y)$ between roughage $(R)$ and yeast $(Y)$ addition revealed that yeast addition decreased the contribution of DM in case of AS and BH than those of non-supplemented one (Table 4). However, bot FAY- and FAY' showed unclear trend but lower in their values than that in AS and BH. Percent contribution of roughages as TDN or DCP requirements for ewes followed the same pattern, where the higher values were recorded during the late gestation period than the other two periods. Therefore, this may explain the reason for lower foetal gain in the present study (ranged from 5.32 to $7.30 \mathrm{~kg})$ as compared to that $(10.02-13.60 \mathrm{~kg})$ reported by Shawket et al. (2015). On the other hand we can notice that yeast addition enhanced the contribution percentage of TDN and DCP in case of both AS and BH but lowered in FA as illustrated in Table 4. In overall view the contribution of roughages to ewes requirements during gestation and suckling periods ranged as follows: $29.98-76.68 \%$ as DM; $49.32-60.46$ as TDN\% and $59.71-71.53$ as DCP\%. 
Table 4 - Computed of roughage nutrients contribution as percentage of requirements* for ewes during different physiological stages

\begin{tabular}{|c|c|c|c|c|c|c|c|c|c|c|}
\hline \multirow{2}{*}{ Treatment** } & & \multicolumn{3}{|c|}{$\%$ of DM Requirement } & \multicolumn{3}{|c|}{$\%$ of TDN Requirement } & \multicolumn{3}{|c|}{$\%$ of DCP Requirement } \\
\hline & & EG & LG & SP & EG & LG & SP & EG & $\mathbf{L G}$ & SP \\
\hline \multirow{3}{*}{$\mathbf{R}$} & $\mathrm{BH}$ & 64.75 & 42.14 & 41.80 & 50.31 & 57.43 & 52.85 & 59.86 & 69.35 & 67.83 \\
\hline & FA & 27.86 & 28.39 & 31.98 & 55.55 & 58.73 & 51.49 & 64.09 & 70.29 & 66.90 \\
\hline & AS & 71.57 & 56.39 & 57.95 & 58.18 & 59.64 & 50.48 & 66.22 & 70.94 & 66.21 \\
\hline \multirow{2}{*}{$\mathbf{Y}$} & $\mathbf{Y}$ & 57.56 & 44.94 & 44.50 & 54.85 & 58.13 & 52.13 & 63.53 & 69.86 & 67.34 \\
\hline & $\mathbf{Y}^{+}$ & 51.95 & 39.86 & 43.39 & 54.53 & 59.07 & 51.06 & 63.27 & 70.54 & 66.62 \\
\hline \multirow{6}{*}{$\mathbf{R} * \mathbf{Y}$} & BHY- & 66.29 & 46.86 & 44.18 & 50.42 & 55.29 & 51.27 & 59.96 & 67.81 & 66.76 \\
\hline & $\mathrm{BHY}^{+}$ & 63.15 & 37.56 & 39.42 & 50.12 & 59.46 & 54.50 & 59.71 & 70.81 & 68.96 \\
\hline & FAY- & 29.80 & 27.42 & 29.98 & 57.39 & 60.29 & 53.63 & 65.59 & 71.41 & 68.37 \\
\hline & $\mathrm{FAY}^{+}$ & 25.79 & 29.41 & 34.06 & 53.97 & 57.25 & 49.32 & 62.82 & 69.22 & 65.43 \\
\hline & ASY- & 76.68 & 60.46 & 59.42 & 56.56 & 58.79 & 51.54 & 64.91 & 70.33 & 66.94 \\
\hline & $\mathrm{ASY}^{+}$ & 66.96 & 52.39 & 56.56 & 59.53 & 60.46 & 49.34 & 67.31 & 71.53 & 65.44 \\
\hline
\end{tabular}

\section{Milk production and composition}

Data of total milk yield $(\mathrm{g} / \mathrm{h} / \mathrm{d})$ and milk composition are presented in Table 5 . The total milk yield (TMY) was significantly $(P<0.05)$ affected by roughage type where the highest value was recorded for BH (434) followed by FA (393) and then AS (383). Also, yeast addition $\left(\mathrm{Y}^{+}\right)$increased $(\mathrm{P}<0.05)$ the TMY $(423)$ compared to $\mathrm{Y}^{-}(384)$ treatment. However, the interaction $\left(R^{*} Y\right)$ showed TMY superiority $(P<0.05)$ for $\mathrm{BHY}^{+}(449)$ treatment and the lowest one for FAY- (365). Milk fat content was not affected $(\mathrm{P}<0.05)$ by roughage type, yeast addition or their interaction. However, milk protein content was higher for $\mathrm{BH}(5.14 \%)$ than the other types of roughage, but there is no significant difference due to yeast addition. Therefore, the interaction showed BHY-as the highest protein value (5.28\%) and FAY- as the lowest one (4.68\%).

The results of total solids content in milk showed high values for FA and AS silage compared to BH, this may because of the apparently inverse relationship with TMY and positively related to milk ash content. However, El-Saadany and Omar (2018) attributed the reduction in milk total solids to a decrease in both fat and protein contents other than the ash content as described by El-Saadany et al. (2016) where they recorded values of milk ash content 0.96 and $0.82 \%$ for Atriplex and hay groups, respectively.

No significant difference was observed between AS and BH in the production of ECM, as well as the MEV expressed as Kcal/kg. Addition of yeast led to a significant improvement for the ECM by $7.84 \%$ compared to no addition. Yeast improved the ECM by 10.6, 23.8 and 5.52\% when added to BH, FA and AS diets, respectively as compared to those diets without yeast. Calculated energy corrected milk (ECM, g/d) showed the highest $(P<0.05)$ values in $B H(52.7), Y^{+}(509)$ and $\mathrm{BHY}^{+}$(554) but the lowest one recorded in FA (459), $\mathrm{Y}^{-}$(472) and ASY- (471), for R, $\mathrm{Y}$ and $\mathrm{R}^{*} \mathrm{Y}$ treatments, respectively. On the other hand, calculated milk energy value $(\mathrm{MEV}, \mathrm{kcal} / \mathrm{kg})$ was not affected $(P>0.05)$ by dietary factors or their interaction under investigation.

In comparison with our results, Abu-Zanat and Tabbaa, (2006) found that milk yield was not affected by feeding ewes on different proportion (0,50 and 100\%) of saltbush foliage diets with concentrate. Also, EL-Saadany and Omar (2018) recorded significantly $(P<0.05)$ lowest values of milk production in Barki ewes fed Atriplex diet as compared to control one. But they cleared that fat content in milk of ewes was not affected by the dietary treatment during all lactation weeks. Fat content ranged between 6.6 and $7.8 \%$. Protein content was, as a general , low significantly affected by dietary treatment, being slightly higher in milk of ewes fed on Atriplex than in Hay groups, at all lactation weeks. The present results were different from that found by El-Gohary et al. (2017), this may be attributed to differ concentrate feed mixture supplemented with either hay or Atriplex fed to Barki ewes. they recorded the higher $(P<0.05)$ value of the average daily milk yield $\mathrm{kg} / \mathrm{head}$ for ewes fed hay $(0.916 \mathrm{~kg} / \mathrm{head})$ than that fed Atriplex which was $0.814 \mathrm{~kg} / \mathrm{head}$. They attributed the high milk yield due to higher dietary CP and EE. Also, they revealed that there were no significant differences between ewe groups for overall means of milk fat $\%$ that were 6.56 , and $6.86 \%$ for hay and Atriplex groups, respectively. They added that ewes of hay group had lower $(P<0.05)$ milk protein\% $(3.77)$ and ash \% $(0.79)$ than Atriplex group (3.99\% and 0.95 , respectively). Overall means of milk total solids percentages revealed insignificant differences and were 17.18 and $\mathbf{1 8 . 0 1 \%}$ for hay and Atriplex groups, respectively. In addition, El-Saadany et al. (2016) concluded that milk fat and Total solids (TS) contents were insignificantly ( $P>0.05)$ affected by hay or Atriplex diet during all lactation weeks, being fat\% ranged between 6.8 and $7.8 \%$ and TS\% 17.05-18.95. However, Protein content was significantly $(P<0.05)$ higher in milk of ewes of Atriplex than in hay group. They attributed these results to the negative relationship between protein content and milk yield, which was significantly $(P<0.05)$ lower in Atriplex than in hay.

Concerning silage effect, Shawket et al. (2015) found that ewe fed Atriplex+Acacia silage diet had higher daily milk production $(\approx 333 \mathrm{ml})$, while dams fed control or fresh Atriplex+Acacia had lower daily milk production with no significant differences $(\approx 300$ and $298 \mathrm{ml}$, respectively). Although, the DMI of ewes fed Atriplex+Acacia silage diet was slightly higher 
than those fed either the control or fresh Artiplex+Acacia diets during late gestation and suckling, it was observed that the dietary treatments had no significant effect on ewe's milk yield. This could attributed to the negative effects of secondary chemical compounds (oxalates and tannins) presented in the browse of Atriplex and Acacia (Abu-Zanat and Tabbaa, 2003). Similar to our results, Mousa, et al. (2012), Zaleska et al. (2015) and Elaref et al. (2020) reported higher daily and total milk yield in dairy sheep supplemented with yeast. Other studies reported no differences in milk production with yeast inclusion (Masek et al., 2008). These discrepancies could be associated with differences in breeds, stage of lactation, forage type, source of the yeast culture and feeding strategy (Alshaikh et al., 2002). No changes in milk composition noted in the present study is consistent with previous reports by Baiomy (2011) in dairy sheep and Salama et al. (2002) in dairy goat. However, other studies observed change in milk composition with dried yeast supplementation (Mousa et al., 2012 and Zaleska et al., 2015). Mousa et al. (2012) pointed out that conflicting results from various yeast studies might have resulted from variations in feeding systems (feeding frequency, ration composition, dose of yeast and strains employed), animal (species, age and physiological state) and environmental conditions.

\section{Table 5 - Total milk yield and composition as affected by different roughages and dry yeast addition.}

\begin{tabular}{|c|c|c|c|c|c|c|c|c|}
\hline \multicolumn{2}{|c|}{ Treatment* } & $\begin{array}{c}\text { TMY* } \\
\text { (g/h/d) }\end{array}$ & $\begin{array}{l}\text { Fat } \\
(\%)\end{array}$ & $\begin{array}{c}\text { Protein } \\
(\%)\end{array}$ & $\begin{array}{l}\text { Ash } \\
\text { (\%) }\end{array}$ & $\begin{array}{l}\text { TS } \\
(\%)\end{array}$ & $\begin{array}{l}\text { ECM } \\
(g / d)\end{array}$ & $\begin{array}{c}\text { MEV } \\
\text { (kcal/kg) }\end{array}$ \\
\hline \multirow{3}{*}{$\mathbf{R}$} & $\mathrm{BH}$ & $434^{a}$ & $4.11^{a}$ & $5.14^{a}$ & $0.86^{b}$ & $15.13^{b}$ & $527^{a}$ & $270^{a}$ \\
\hline & FA & $393^{a b}$ & $3.97^{a}$ & $4.74^{b}$ & $0.87^{a b}$ & $16.45^{a}$ & $459^{b}$ & $267^{a}$ \\
\hline & AS & $383^{b}$ & $4.53^{a}$ & $5.04^{a b}$ & $0.90^{a}$ & $17.44^{a}$ & $483^{a b}$ & $273^{a}$ \\
\hline \multirow{2}{*}{$\mathbf{Y}$} & $\mathbf{Y}^{-}$ & $384^{b}$ & $4.31^{a}$ & $4.96^{\mathrm{a}}$ & $0.89^{a}$ & $16.61^{a}$ & $472^{b}$ & $271^{a}$ \\
\hline & $\mathbf{Y}^{+}$ & $423^{a}$ & $4.10^{a}$ & $4.99^{a}$ & $0.87^{a}$ & $16.08^{a}$ & $509^{a}$ & $269^{a}$ \\
\hline \multirow{6}{*}{$\mathbf{R} * \mathbf{Y}$} & BHY- & $419^{a b}$ & $3.88^{a}$ & $5.28^{a}$ & $0.87^{a b}$ & $15.93^{\mathrm{bc}}$ & $501^{b}$ & $269^{a}$ \\
\hline & $\mathrm{BHY}^{+}$ & $449^{a}$ & $4.34^{a}$ & $5.00^{a b}$ & $0.85^{b}$ & $14.33^{c}$ & $554^{a}$ & $272^{a}$ \\
\hline & FAY- & $356^{b}$ & $3.90^{\mathrm{a}}$ & $4.68^{b}$ & $0.87^{a b}$ & $15.91^{b c}$ & $411^{d}$ & $266^{a}$ \\
\hline & $\mathrm{FAY}^{+}$ & $431^{a b}$ & $4.04^{a}$ & $4.80^{\mathrm{ab}}$ & $0.86^{a b}$ & $17.00^{\mathrm{ab}}$ & $509^{b}$ & $268^{a}$ \\
\hline & ASY- & $376^{a b}$ & $4.53^{a}$ & $4.91^{\mathrm{ab}}$ & $0.92^{a}$ & $17.97^{\mathrm{a}}$ & $471^{c}$ & $273^{a}$ \\
\hline & $\mathrm{ASY}^{+}$ & $390^{a b}$ & $4.54^{a}$ & $5.18^{a b}$ & $0.88^{a b}$ & $16.92^{\mathrm{ab}}$ & $497^{b}$ & $274^{a}$ \\
\hline
\end{tabular}

\section{Nutrients intake and conversion}

Table 6 illustrates the feed conversion expressed as DM, TDN and DCP to milk yield (g/g). The lowest value means the better-feed conversion efficiency. It can be seen that AS treatment has the highest $(P<0.05)$ values for the three parameters of feed conversion $(4.14,2.67,0.369 \mathrm{~g} / \mathrm{g}$, respectively) as compared to the other comparable roughages (BH and FA). However, $\mathrm{Y}^{+}$was better than $\mathrm{Y}^{-}$concerning DM conversion being values were 3.18 vs. 3.52 , but there were no significant $(P<0.05)$ differences concerning both TDN and DCP conversion. The interaction $(R * Y)$ showed that both AS treatments either without yeast (ASY) or with yeast $\left(\mathrm{ASY}^{+}\right)$was lower efficiency to convert DM, TDN and DCP to milk when compared to the other treatments.

Table 6 - Nutrients intake and their conversion efficiency to milk passed on feeding ewes on different roughages and dry yeast

\begin{tabular}{|c|c|c|c|c|c|c|c|}
\hline \multirow{2}{*}{\multicolumn{2}{|c|}{ Treatment* }} & \multicolumn{3}{|c|}{ Nutrients intake (g/d) } & \multicolumn{3}{|c|}{ Nutrients converted to milk (g/g) } \\
\hline & & DM & TDN & DCP & DM & TDN & DCP \\
\hline \multirow{3}{*}{$\mathbf{R}$} & $\mathrm{BH}$ & $1290^{b}$ & $826^{b}$ & $115^{b}$ & $2.97^{b}$ & $1.90^{b}$ & $0.264^{b}$ \\
\hline & FA & $1168^{c}$ & $775^{c}$ & $108^{b}$ & $2.97^{b}$ & $1.97^{b}$ & $0.275^{b}$ \\
\hline & AS & $1587^{a}$ & $1022^{a}$ & $141^{\mathrm{a}}$ & $4.14^{\mathrm{a}}$ & $2.67^{a}$ & $0.369^{a}$ \\
\hline \multirow{2}{*}{$\mathbf{Y}$} & $\mathrm{Y}$ & $1351^{a}$ & $844^{b}$ & $112^{b}$ & $3.52^{a}$ & $2.20^{a}$ & $0.291^{a}$ \\
\hline & $\mathbf{Y}^{+}$ & $1347^{a}$ & $907^{a}$ & $131^{\mathrm{a}}$ & $3.18^{b}$ & $2.14^{a}$ & $0.310^{\mathrm{a}}$ \\
\hline \multirow{6}{*}{$\mathbf{R} * \mathbf{Y}$} & BHY- & $1348^{b}$ & $828^{c}$ & $112^{c}$ & $3.22^{b}$ & $1.98^{b}$ & $0.268^{c}$ \\
\hline & $\mathrm{BHY}^{+}$ & $1231^{c}$ & $819 c$ & $116^{c}$ & $2.74^{b}$ & $1.82^{b}$ & $0.259^{c}$ \\
\hline & FAY- & $1111^{d}$ & $718^{d}$ & $88.7^{d}$ & $3.12^{b}$ & $2.02^{b}$ & $0.249^{c}$ \\
\hline & $\mathrm{FAY}^{+}$ & $1226^{c}$ & $833^{c}$ & $129^{b}$ & $2.84^{b}$ & $1.93^{b}$ & $0.299^{b}$ \\
\hline & ASY- & $1592^{a}$ & $975^{b}$ & $135^{b}$ & $4.23^{a}$ & $2.59^{a}$ & $0.360^{\mathrm{a}}$ \\
\hline & $\mathrm{ASY}^{+}$ & $1584^{a}$ & $1069^{a}$ & $147^{a}$ & $4.06^{a}$ & $2.74^{a}$ & $0.378^{a}$ \\
\hline
\end{tabular}




\section{Performance of suckling lambs}

Ewe's production index as kilograms of lambs born indicates that AS group had lambs with a higher birth weight $(4.04 \mathrm{~kg})$ than groups fed BH $(3.52 \mathrm{~kg})$ or AS $(3.15 \mathrm{Kg})$. Yeast addition $\left(\mathrm{Y}^{+}\right)$to ewes diets increased birth weight of their lambs by $\mathbf{2 0 . 3 \%}$ of that un-supplemented one ( $\left.Y^{-}\right)$. In addition, lamb birth weight was enhanced by about $11.4,25.0$ and $\mathbf{2 5 . 7 \%}$ for ewe groups received yeast with $\mathrm{BH}$, FA and AS, respectively as compared to the others received the same roughages without yeast. These results are matching with the data of ewes body weight gain at 150d of gestation (as illustrate in Table 2). The weaning weight and average daily gain of lambs showed the same significance $(P<0.05)$ pattern. Where $\mathrm{BH}, \mathrm{Y}^{+}, \mathrm{BHY}^{+}, \mathrm{AFY}^{+}, \mathrm{ASY}^{+}$were higher than the other groups within $\mathrm{R}, \mathrm{Y}$ and $\mathrm{R}^{*} \mathrm{Y}$ treatments, respectively. This indicates that feeding roughages with yeast was preferred for gaining lambs in a high weaning weight. In addition, the lowest weaned weight for FA feeding group may be an indicator for low fat and protein concentration of milk (as illustrate in Table 5).

\section{Table 7 - Performance of suckling lambs, milk conversion efficiency and economic indicators}

\begin{tabular}{|c|c|c|c|c|c|c|c|c|c|c|c|}
\hline \multirow[t]{2}{*}{ Item } & \multicolumn{2}{|c|}{ Roughage (R) } & \multicolumn{3}{|c|}{ Yeast (Y) } & \multicolumn{5}{|c|}{$\mathbf{R} * \mathbf{Y}$} & \multirow[b]{2}{*}{ ASY+ $^{+}$} \\
\hline & BH & FA & AS & $\mathbf{Y -}$ & $\overline{\mathbf{Y}^{+}}$ & BHY- & BHY+ $^{+}$ & FAY- & FAY' $^{+}$ & ASY- & \\
\hline \multicolumn{12}{|c|}{ Lamb performance } \\
\hline $\mathrm{BiW}(\mathrm{kg})$ & $3.52^{\mathrm{b}}$ & $3.15^{c}$ & $4.04^{a}$ & $3.24^{\mathrm{b}}$ & $3.90^{a}$ & $3.33^{b}$ & $3.71^{b}$ & $2.80^{c}$ & $3.50^{b}$ & $3.58^{b}$ & $4.50^{a}$ \\
\hline WW (kg) & $22.51^{a}$ & $18.09 \mathrm{c}$ & $21.06^{b}$ & $19.47^{b}$ & $21.63^{a}$ & $21.44^{b}$ & $23.57^{a}$ & $17.22^{\mathrm{d}}$ & $18.95^{c}$ & $19.75^{c}$ & $22.37^{b}$ \\
\hline ADG (g) & $211^{a}$ & $166^{c}$ & $189^{b}$ & $180^{b}$ & $197^{a}$ & $201^{b}$ & $221^{a}$ & $160^{d}$ & $172^{\mathrm{cd}}$ & $180^{c}$ & $199 b$ \\
\hline $\begin{array}{l}\text { Milk conversion } \\
\text { efficiency (MCE) } \\
\mathrm{g} / \mathrm{g}\end{array}$ & $2.06^{b}$ & $2.37^{a}$ & $2.03^{b}$ & $2.13^{a}$ & $2.15^{a}$ & $2.08^{\mathrm{ab}}$ & $2.03^{b}$ & $2.23^{a b}$ & $2.51^{a}$ & $2.09^{b}$ & $1.96^{b}$ \\
\hline \multicolumn{12}{|c|}{ Economic indicators } \\
\hline TFC, LE & 601 & 447 & 521 & 523 & 523 & 626 & 576 & 428 & 466 & 515 & 528 \\
\hline PTWG, LE & 1424 & 1121 & 1277 & 1217 & 1330 & 1358 & 1490 & 1082 & 1159 & 1213 & 1340 \\
\hline PWW, LE & 1688 & 1357 & 1580 & 1460 & 1622 & 1608 & 1768 & 1292 & 1421 & 1481 & 1678 \\
\hline Net return, LE & 1087 & 910 & 1059 & 937 & 1099 & 982 & 1192 & 864 & 955 & 966 & 1150 \\
\hline $\mathrm{EE}$ & $1.81^{b}$ & $2.04^{a}$ & $2.03^{a}$ & $1.79^{b}$ & $2.10^{\mathrm{a}}$ & $1.59^{c}$ & $2.07^{a}$ & $2.02^{a}$ & $2.05^{a}$ & $1.88^{b}$ & $2.18^{a}$ \\
\hline
\end{tabular}

Abu-Zanat and Tabbaa (2006) concluded that feeding Atriplex browse with concentrate did not cause any significant effect on milk production, birth weight, weaning weight or growth rates of lambs. Also, El-Gohary et al. (2017) found that feeding tanniniferous plants shrubs (acacia, Atriplex and cassava) as alternatives to Berseem hay did not exhibit any significant differences in lambs birth weight but differences $(P<0.05)$ in total gain and average daily gain of lambs were observed. On the other hand, these results are not in accordance with those obtained by Mohammady et al. (2014) who reported higher weaning weight and daily gain $(P<0.05)$ in Barki lambs fed $\mathrm{BH}$ when compared with those fed tanniniferous plants shrubs. In addition, El-Saadany et al. (2016) found significant $(P<0.05)$ differences in average birth weight of lambs that was higher in Atriplex treatment group (3.83 kg) than in control group (3.69 kg), however the ADG was not affected being values were 150 vs. $156 \mathrm{~g}$, respectively.

In contrast to the present results, Shawket et al. (2015) recorded that lamb's birth weight was not affected by feeding ewes fresh or silage shrubs. However, feeding mixture of Atriplex+Acacia either fresh or silage decreased lamb weaning weight by about 11.6 and $\mathbf{1 3 . 8} \%$ than control group, respectively which indicate low nutritional quality of silage diet as compared with that in the present study. Consisting with our result, they found the ADG from birth to weaning of control lambs group was higher than those of other two tested groups fed either fresh or silage (190 vs. 165 and 160 $\mathrm{g} /$ day, respectively). It was noticeable that the daily gain of halophytic fed lambs was comparable to the recorded average daily gain value ( $160 \mathrm{~g} /$ day) for NRC fed lambs that found by Farid et al. (2005).

Positive effects of yeast was confirmed by Abdel-Gawad (2012) who indicated that birth weight was significantly higher $2.92 \mathrm{~kg}$ and $3.11 \mathrm{~kg}$ vs. $2.68 \mathrm{~kg}$ with increasing levels of lecture yeast $(2,1 \mathrm{and} 0 \mathrm{~g} / \mathrm{h} / \mathrm{d}$, respectively. Also, the levels of yeast ( $1 \mathrm{~g}$ or $2 \mathrm{~g} / \mathrm{h} / \mathrm{d}$ ) had significant positive effect on weaning weight (12.88 $\mathrm{kg}$ and $13.82 \mathrm{~kg}$, respectively) vs. $11.45 \mathrm{~kg}$ in control group. This was reflected on ADG, being $165.9 \mathrm{~g}$ and $178.6 \mathrm{~g}$ for groups received $1 \mathrm{and} 2 \mathrm{~g}$ yeast/h/d compared with $146.2 \mathrm{~g}$ for control. This increase in daily gain of offspring may be due to the increase of TMY. Generally increasing milk yield for lactating ewes represents an important factor for the production of robust lambs at weaning.

The total net return per ewe was markedly better in $\mathrm{BH}$ and $\mathrm{Y}^{+}(807 \mathrm{LE})$ for $\mathrm{R}$ and $\mathrm{Y}$ treatments (Table 7). However the interaction $\left(R^{*} Y\right)$ showed the $\mathrm{BHY}^{+}$followed by $\mathrm{ASY}^{+}$as the better net return when compared to the other treatments.

Under the present experimental conditions, weaning weight as a final index of the productive efficiency of ewes as relative to the hay group (calculated from data in Table 7) was $93.6 \%, 80.4 \%$ for AS and FA, respectively. Generally, adding yeast to different roughage diets during suckling period led to an increase in weaning weight by $11.1 \%$ compared 
to those without yeast. Adding yeast to BH, FA and SA diets improved weaning weight by $9.93,10.05$ and $13.27 \%$, respectively compared with those without yeast.

The economic efficiency (EE) was significantly $(\mathrm{P}<0.05)$ higher in both FA and AS compared to BH (Table 7), these mainly due to its low price (only labor cost for cut and carry or processing silage) because its availability as a range plant put not return to its nutritive value. Also, yeast addition $\left(\mathrm{Y}^{+}\right)$resulted in higher $(\mathrm{P}<0.05)$ EE compared to $\mathrm{Y}^{-}$. The EE was enhanced $(P<0.05)$ by adding yeast to $\mathrm{BH}$ diet with 0.48 ; however, it was 0.33 for silage and 0.03 for FA diets. Concerning the yeast effect Habeeb (2017) reported that Yea-Sacc $® 1026$ helps of ruminant animals achieve their full potential-cost effectively through better utilization of feed.

\section{Digestibility and feeding values}

The digestibility coefficients of the experimental diets and their feeding values are presented in Table 8. Results indicated that digestibilities of DM, CP and EE of both fresh and silage Atriplex were higher than that of hay roughage. These findings may reflect the high quality of silage and/or the positive associative effect between barley and Atriplex in fresh or silage form. On the other hand, the experimental roughages did not affect the digestibility of OM, CP and NFE. It is of interest that most nutrients (DM, CP and EE) digestibility were comparable between fresh and silage foliage and they are higher $(\mathrm{P}<0.05)$ than $\mathrm{BH}$ which in contrast with other studies (Khattab, 2007, Fayed et al., 2010 and Shawket et al., 2015). They reported that control diet was superior in digestibility of nutrients followed by silage and then fresh foliage. The present results could be explained by barley grain interaction effect that showed higher improvement when given with FA or AS than BH or in other word, The lower the quality of the roughage, the greater the improvement by barley. The high solubility of Atriplex nitrogen could be the reason for the high CP digestibility reported herein and in most studies (Ben Salem et al., 2010).

Yeast group $\left(\mathrm{Y}^{+}\right)$enhanced the digestibility of all nutrients except for NFE that was unaffected (Table 8). The same pattern was observed in digestibility of DM, OM, CP and CF when yeast added with roughages but the highest values were observed for $\mathrm{FAY}^{+}$diet. Which meaning that yeast showed high positive effect in case of low quality forages like Atriplex. The EE digestibility was in the lowest value for BHY- $(68.64 \%)$ diet as compared with the other diets. The digestibility of NFE was not significantly $(P>0.05)$ affected by roughage type, yeast addition and their interaction. The present results were in harmony with that reported by Habeeb (2017) who stated that the apparent digestibility of nutrients and the nutritive values of diet were enhanced by yeast addition compared to the control one. This may be due to increase the number of bacteria in the rumen or stimulate some of the rumen bacteria sp. Like proteolytic or cellulolytic bacteria or both.

\section{Table 8 - Digestibility and feeding values of the experimental rations fed to Barki ewes}

\begin{tabular}{|c|c|c|c|c|c|c|c|c|c|c|}
\hline \multirow{2}{*}{\multicolumn{2}{|c|}{ Treatment* }} & \multirow{2}{*}{$\begin{array}{l}\text { BW } \\
\text { (kg) }\end{array}$} & \multirow[b]{2}{*}{ DM } & \multicolumn{5}{|c|}{ Nutrients digestibility (\%) } & \multicolumn{2}{|c|}{ Feeding value (\%) } \\
\hline & & & & OM & $\mathbf{C P}$ & $\mathbf{C F}$ & EE & NFE & TDN & DCP \\
\hline \multirow{3}{*}{$\mathbf{R}$} & $\mathrm{BH}$ & $40.49^{a}$ & $65.26^{b}$ & $65.66^{a}$ & $65.13^{b}$ & $48.59^{a}$ & $72.64^{b}$ & $73.87^{a}$ & $64.01^{\mathrm{a}}$ & $8.88^{a}$ \\
\hline & FA & $40.99^{a}$ & $71.69 a$ & $65.85^{a}$ & $76.67^{a}$ & $45.80^{a}$ & $78.88^{a}$ & $77.35^{a}$ & $66.31^{a}$ & $9.24^{a}$ \\
\hline & AS & $41.16^{a}$ & $70.06^{a}$ & $65.44^{a}$ & $73.85^{a}$ & $46.92^{a}$ & $80.99 a$ & $75.67^{a}$ & $64.40^{a}$ & $8.90^{a}$ \\
\hline \multirow{2}{*}{$\mathbf{Y}$} & $\mathbf{Y}^{-}$ & $39.93^{a}$ & $67.10^{b}$ & $60.51^{b}$ & $70.30^{b}$ & $43.13^{b}$ & $75.81^{b}$ & $74.80^{a}$ & $62.45^{b}$ & $8.27^{b}$ \\
\hline & $\mathrm{Y}^{+}$ & $41.83^{a}$ & $70.90^{a}$ & $70.78^{a}$ & $73.47^{a}$ & $51.08^{a}$ & $79.19 a$ & $76.46^{a}$ & $67.34^{a}$ & $9.74^{a}$ \\
\hline \multirow{6}{*}{$\mathbf{R} * \mathbf{Y}$} & BHY- & $40.28^{a}$ & $64.37^{c}$ & $64.30^{\mathrm{bc}}$ & $64.91^{\mathrm{c}}$ & $47.77^{a b}$ & $68.64^{b}$ & $73.07^{a}$ & $61.46^{b}$ & $8.33^{c}$ \\
\hline & $\mathrm{BHY}^{+}$ & $40.70^{a}$ & $66.15^{b c}$ & $67.01^{\mathrm{ab}}$ & $65.35^{c}$ & $49.42^{\mathrm{ab}}$ & $76.65^{a}$ & $74.68^{a}$ & $66.56^{a b}$ & $9.43^{b}$ \\
\hline & FAY- & $39.88^{a}$ & $68.93^{a b c}$ & $58.63^{c}$ & $73.38^{b}$ & $40.89^{b}$ & $77.22^{a}$ & $76.76^{a}$ & $64.66^{a b}$ & $7.98^{c}$ \\
\hline & $\mathrm{FAY}^{+}$ & $42.10^{a}$ & $74.45^{a}$ & $73.06^{a}$ & $79.97^{a}$ & $50.72^{a}$ & $80.54^{a}$ & $77.94^{a}$ & $67.96^{a}$ & $10.50^{a}$ \\
\hline & ASY- & $39.63^{a}$ & $68.01^{b c}$ & $58.61^{c}$ & $72.63^{b}$ & $40.73^{b}$ & $81.58^{a}$ & $74.59^{a}$ & $61.23^{b}$ & $8.51^{c}$ \\
\hline & $\mathrm{ASY}^{+}$ & $42.70^{a}$ & $72.12^{\mathrm{ab}}$ & 72.27ab & $75.08^{\mathrm{ab}}$ & $53.11^{\mathrm{a}}$ & $80.39 a$ & $76.76^{a}$ & $67.51^{\mathrm{a}}$ & $9.30^{b}$ \\
\hline
\end{tabular}

It is of interest to find comparable $(P>0.05)$ values of feeding values as TDN or DCP for BH, FA and AS diets, but as Atriplex CP extensively degraded to ammonia in the rumen, therefore the protein value of the diet was much lower than indicated by its DCP content. The similar values of TDN among BH, FA and AS may be attributed to similar digestibility of both CF and EE. Nevertheless, there were no significant differences between nutritive value as TDN and DCP percentage of the two halophytic diets fresh or silage which was in accordance with results of Shawket et al. (2015). But the same authors reported that TDN and DCP values of the control were higher $(p<0.05)$ than those of fresh and silage Atriplex+Acacia diets (69.73 and 9.01 vs. 63.84, 8.60 and 64.18, $7.68 \%$, respectively). Also, Khattab (2007) concluded that TDN\% for diets based on barley grain covered100\% of energy requirement (according to Kearl, 1982) and roughages as Berseem hay and fresh or silage Atriplex was significantly different being values $67.87 \mathrm{a}, 60.14 \mathrm{c}$ and $62.54 \mathrm{~b} \%$, respectively. The corresponding values of DCP \% were $9.02,9.52$ and $9.00(P<0.05)$. 
On the other hand, yeast addition increased TDN and DCP by about 7.83 and $17.78 \%$, respectively over than that un-supplemented one (Table 8). The interaction showed that, yeast addition to all roughages always increased their TDN\% and DCP\% values as compared to roughages without yeast addition. The highest $(\mathrm{P}<0.05)$ values were recorded for FAY' being $67.96 \%$ TDN and $10.50 \%$ DCP. In addition, ASY+ showed comparable $(P<0.05)$ value of TDN \% (67.51) with that of $\mathrm{FAY}^{+}$(67.96). In agreement with these results, Saleh et al. (2004) found that the TDN \% was increased from 75.43 in control treatment to 76.31 in active dry yeast treatment. More improvement in nutritive values were reported by Allam et al. (2001) who found that TDN and DCP values increased from 73.73 to $81.88 \%$ and from 13.19 to $15.32 \%$, respectively, when yeast was added at level of $2.5 \mathrm{~g} / \mathrm{head} / \mathrm{day}$.

\section{Site of OM digestibility and microbial protein synthesized in the rumen}

Data of Table 9 illustrate the results of in situ OM disappearance (ISOMD \%) of the experimental rations and used it for calculation of the fraction of $\mathrm{OM}$ digestion and the microbial protein synthesized in the rumen. Data showed that $\mathrm{BH}$, $\mathrm{Y}^{+}$and $\mathrm{BHY}^{+}$were the highest $(\mathrm{P}<0.05)$ ISOMD \% in $\mathrm{R}, \mathrm{Y}$ and $\mathrm{R}^{*} \mathrm{Y}$ treatment, respectively being corresponding values 78.7, 77.17 and $82.55 \%$. The site of OM digestion emphasize that the rumen have the highest efficiency in digestion the organic matter compared to the lower gut. It can be notice that AS showed the highest value of OMD post rumen (20.31\%), this can explained by the effect of barley plus silage on fermentation in the rumen making the $\mathrm{pH}$ tends to be acidic (as discussed later in Table 12) that decreased the digestion of OM in the rumen but increased post the rumen. The positive effect of yeast addition on OM digestion in the rumen of all treatments was cleared either in $Y$ or $R^{*} Y$ treatments.

The ranges of synthesized MCP in rumen showed the superiority of BH (203-179 g/d) followed by AS (172-152 g/d) and then FA rations (120-106 g/d). In addition, the supplemented yeast ration was higher (169-149 $\mathrm{g} / \mathrm{d})$ than that unsupplemented one (160-141 g/d). The $A * Y$ effect declared higher values of MCP range in all ration supplemented with yeast $\left(\mathrm{BHY}^{+}>\mathrm{SAY}^{+}>\mathrm{FAY}^{+}\right)$compared with that un-supplemented (BHY->SAY-> FAY-).

In the present study, ruminal and post-ruminal OM disappearances of the feeds were evaluated to provide more reliable information for these feeds. Moreover, production of individual ruminants depends not only on genetic characteristics but also on the quantity and quality of nutrients available for intermediary metabolism (Solanas et al., 2003). The supply of nutrients is the result of voluntary intake and nutrient concentration of feed intake (Merkel et al., 1999). Voluntary intake of a feed depends essentially on the rate of ruminal and post-ruminal digestion of digestible nutrients. Attia et al. (2018) found that Atriplex halimus was digested in the rumen by $79.4 \%$ as true DM degradability and the intestinal protein digestion was $46.9 \%$. Furthermore, Ben Salem et al. (2002) reported that the efficiency of microbial protein synthesis was significantly improved in sheep receiving Atriplex. They added that BG+FA increased micriobial $\mathrm{N}$ supply by $4.8 \mathrm{~g} / \mathrm{kg}$ DOMI (P<0.001) compared with barley alone. Otherwise, Ben Salem et al. (2010) concluded that feeding a high-energy supplement such as barley can improve the feeding value of saltbush pastures by providing energy to ruminal microbes to produce microbial protein, stimulate carbohydrate digestion and detoxify secondary compounds. Miller-Webster et al. (2002) reported that yeast have efficient roles on the rumen fermentation and nutrient digestibility, which improve ammonia uptake and microbial protein production. Moreover, Dawson et al. (1990) suggested that yeast enhances fiber digestion and increases the number of cellulolytic bacteria in the rumen. The recent data of MCP ranges were higher than the range of 134-159g that found for control diet fed to Barki lambs in earlier study by Kewan (2013).

\section{Table 9 - Digestion fractions of OM and Calculation of the microbial protein synthesized in the rumen of ewes}

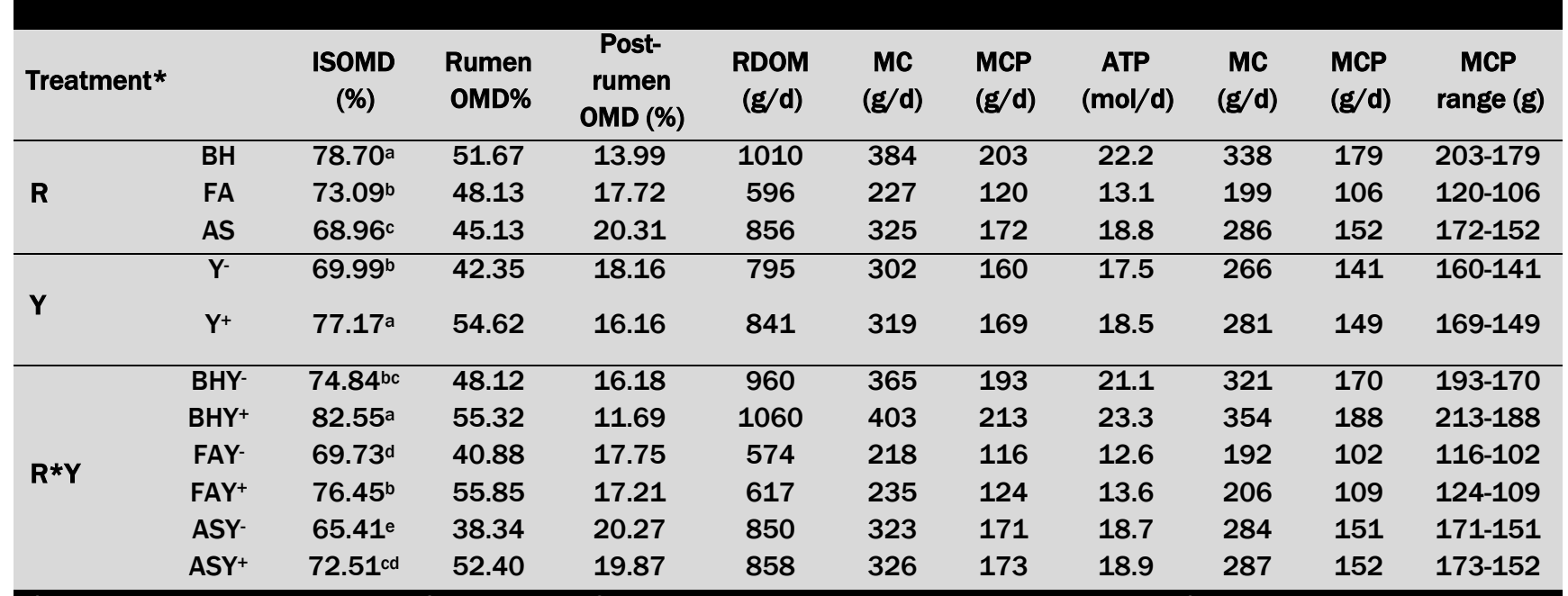




\section{Nitrogen utilization}

The data of nitrogen utilization as affected by types of roughage, yeast addition and their interaction are shown in Table 10. Although significant $(P<0.05)$ differences were observed in roughages $N$ intake and $N$ excreted via feces or urine, the $\mathrm{N}$ retained was similar $(\mathrm{P}>0.05)$ among the experimental roughages groups. The $\mathrm{NR}$ as a relative to feed $\mathrm{N}$ intake (FNI) or absorbed $\mathrm{N}$ was significantly higher for FA ration than AS or BH rations. Yeast addition showed positive significant $(P<0.05)$ effect on the parameters of $N$ utilization except for $N$ excretion in urine. It can be noticed that the $N R$ increased 2.60 times by yeast addition. High $(P<0.05)$ NR values observed in $\mathrm{BHY}^{+}(7.83 \mathrm{~g} / \mathrm{d}), \mathrm{FAY}^{+}(7.03 \mathrm{~g} / \mathrm{d})$ and $\mathrm{ASY}^{+}$ $(7.23 \mathrm{~g} / \mathrm{d})$ groups mainly attributed to the high intake of $\mathrm{N}$ that were $28.25,17.85$ and $19.60 \mathrm{~g} / \mathrm{d}$, respectively. The same pattern was observed for the ratio of $\mathrm{NR}$ to the absorbed $\mathrm{N}$ being values were 42.44, 49.23 and 49.12 for $^{\mathrm{BHY}} \mathrm{Y}^{+}, \mathrm{FAY}^{+}$and $\mathrm{ASY}^{+}$, respectively. It is noticeable that ASY- group revealed the lowest $(\mathrm{P}<0.05)$ value for NR $(1.97)$, NR/FNI ratio (12.63\%) and NR/absorbed $\mathrm{N}$ ratio (17.39\%).

Despite sheep consuming $\mathrm{BH}$ diets excreted more $\mathrm{N}$ in feces and urine as a consequence of a great amount of $\mathrm{N}$ provided by this roughage than those containing fresh or silage Atreplex, the NR was comparable among three groups (BH, FA and AS). However, Ben Salem et al. (2002) reported higher NR for sheep fed Barley+Atreplix mixture diet than those fed a mixture of Barley+Acacia. In addition, Ben Salem et al. (2010) attributed the negative $N$ balance in sheep fed Atriplex alone to the disequilibrium between energy and protein in this shrub species. However, when an energy source, e.g. Barley, was associated to oldman saltbush, sheep and goats retained from 6 to $13 \mathrm{~g} \mathrm{~N} /$ day depending on the amount and the source of energy added to the diet.

Results showed that the main pathway of $\mathrm{N}$ excretion was through urine for all tested groups, these findings may be attributed to either feeding on barley grains which works as a diuretic or excess of ruminal ammonia excreted as $\mathrm{N}$ in urine. The current data were close to that found by Khattab $(2007)$ who concluded that NR was higher $(P<0.05)$ for hay group followed by fresh and silage Atriplex groups being values were 7.11, 4.70 and $4.60 \mathrm{~g} / \mathrm{d}$, respectively. Furthermore, the relative values of NR to NI or N digested were $23.61-43.18 \% ; 16.31-36.41 \%$ and $16.10-34.55 \%$ for the corresponding groups respectively. The same pattern was reported by Shawket et al. (2015) who recorded the highest value of NR by control group followed by the two groups fresh and silage (3.02 vs. 2.13 and $2.31 \mathrm{~g} /$ day, respectively). They added that nitrogen retained as a percent of nitrogen intake (NR/NI\%) was significantly $(\mathrm{P}<0.05)$ higher for control group $(12.93 \%)$ than the other two ewes groups fed Atriplex+Acacia silage diet (11.71\%) or fresh mixture (9.80\%), respectively.

Table 10 - Nitrogen utilization as affected by feeding ewes on different roughages and dry yeast

\begin{tabular}{|c|c|c|c|c|c|c|c|}
\hline Treatment * & & $\begin{array}{l}\text { Feed N intake; } \\
\text { FNI (g/d) }\end{array}$ & $\begin{array}{l}\text { Fecal N } \\
(\mathrm{g} / \mathrm{d})\end{array}$ & $\begin{array}{l}\text { Urine N } \\
\text { (g) }\end{array}$ & $\begin{array}{l}\text { NR } \\
\text { (g) }\end{array}$ & $\begin{array}{c}\text { NR/ FNI } \\
\text { (\%) }\end{array}$ & $\begin{array}{c}\text { NR/ absorbed } \\
\text { N (\%) }\end{array}$ \\
\hline \multirow{3}{*}{$\mathbf{R}$} & $\mathrm{BH}$ & $24.06^{a}$ & $8.37^{a}$ & $10.13^{a}$ & $5.56^{a}$ & $23.11^{b}$ & $35.44^{b}$ \\
\hline & FA & $15.94^{c}$ & $3.65^{c}$ & $7.16^{c}$ & $5.13^{a}$ & $32.18^{a}$ & $41.74^{a}$ \\
\hline & AS & $17.6^{b}$ & $4.58^{b}$ & $8.42^{b}$ & $4.60^{a}$ & $26.14^{b}$ & $35.33^{b}$ \\
\hline \multirow{2}{*}{$\mathbf{Y}$} & $\mathbf{Y}^{-}$ & $16.50^{b}$ & $4.98^{b}$ & $8.69^{a}$ & $2.83^{b}$ & $17.15^{b}$ & $24.57^{b}$ \\
\hline & $\mathrm{Y}^{+}$ & $21.90^{a}$ & $6.08^{a}$ & $8.45^{a}$ & $7.37^{a}$ & $33.65^{a}$ & $46.59^{a}$ \\
\hline \multirow{6}{*}{$\mathbf{R} * \mathbf{Y}$} & BHY- & $19.88^{b}$ & $6.94^{b}$ & $9.65^{a}$ & $3.29^{b}$ & $16.55^{\mathrm{cd}}$ & $25.43^{b c}$ \\
\hline & $\mathrm{BHY}^{+}$ & $28.25^{a}$ & $9.80^{a}$ & $10.62^{a}$ & $7.83^{a}$ & $27.72^{b}$ & $42.44^{a}$ \\
\hline & FAY- & $14.03^{d}$ & $3.73^{\mathrm{cd}}$ & $7.06^{c}$ & $3.24^{b}$ & $23.09 \mathrm{bc}$ & $31.46^{b}$ \\
\hline & $\mathrm{FAY}^{+}$ & $17.85 b^{c}$ & $3.57^{\mathrm{cd}}$ & $7.25^{c}$ & $7.03^{a}$ & $39.38^{a}$ & $49.23^{a}$ \\
\hline & ASY- & $15.60^{\mathrm{cd}}$ & $4.27^{\mathrm{cd}}$ & $9.36^{a b}$ & $1.97^{b}$ & $12.63^{d}$ & $17.39^{c}$ \\
\hline & $\mathrm{ASY}^{+}$ & $19.60^{b}$ & $4.88^{c}$ & $7.49^{b c}$ & $7.23^{a}$ & $36.89 a$ & $49.12^{a}$ \\
\hline
\end{tabular}

and yeast addition. $a, b, c$ : Means within column within treatment with different superscripts differ significantly $(P<0.05)$.

\section{Water utilization}

The roughage type affect $(\mathrm{P}<0.05)$ on free water intake, where the highest value recorded for $\mathrm{BH}$ treatment $($ Table 11). It can be seen that a reverse relationship between drinking water intake and the moisture content of feed. High feed water intake $(P<0.05)$ recorded for sheep fed on FA or AS diets, mainly attributed to high moisture content of that feeds. These in contrast with that reported by Khattab (2007) who concluded significant differences in drinking water (I/d) for ewes fed diets based on barley grain; offered as $100 \%$ of energy requirement that recommended by Kearl (1982); and roughages of hay and fresh or silage of Atreplix foliage, the values were 6.11, 4.62 and 4.84 respectively. In addition, Ben Salem et al. (2002) found that drinking water consumption increased substantially when Atriplex was associated to barley as a supplement. The animal group that received a diet enriched with yeast $\left(\mathrm{Y}^{+}\right)$consumed more free water than that not received yeast (Table 11). The yeast addition increased free water intake by 137, 111 and $25 \%$ for AS, FA and BH as compared to the non-supplemented ones. The treatments $\mathrm{BH}, \mathrm{Y}^{+}, \mathrm{FAY}^{+}$and $\mathrm{ASY}^{+}$showed highest values of free water intake as percent of ash intake. The IWL $\left(g / \mathrm{kg}^{0.82}\right)$ was not affected $(P>0.05)$ by the types of roughage. However, $\mathrm{Y}^{+}$ increased the IWL as compared to $Y$ - Within interaction, the yeast supplemented roughages resulted in a higher IWL value than that of un-supplemented one, and the FAY' group recorded the highest value but ASY- was the lowest one. 
Khattab (2007) and (Ahmed et al., 2015) showed that higher water consumption by animals fed diets containing fresh Atriplex, was due to higher ash content especially Na. However, there was no significant difference between groups, which may indicate an ability of lambs to adapt to the concentrations of salt in the feed on offer, or that the salt concentration was at an acceptable concentration. Such trends are close to those obtained by Ben Salem et al. (2010) who recommended that animals eating Atriplex nummularia must have a relatively high water intake, up to 9 or 10.5 L/kg DM intake/d, in order to excrete the ingested salt. They added that the amount of drinking water consumed by sheep and goats fed on oldman saltbush alone or associated with feed supplements like barley grain varied between 0.5 and $7 \mathrm{~L}$ /day. Askar et al. (2016) attributed the low Atriplex nummularia intake to the limited drinking water supply (4.96 L/kg DM intake/d) that was made available twice daily. On the other hand Fayed et al. (2010) found that insensible water loss $(\mathrm{ml} / \mathrm{h} /$ day $)$ for sheep fed Atriplex was lower $(\mathrm{P}<0.05)$ than those fed alfalfa hay plus barley grains at level $25 \%$ of maintenance energy requirement being value 630 vs. 1056, respectively.

In contrast with current data, Ahmed et al. (2015) found no significant difference in water intake between animals fed Atriplex diet supplemented with Saccharomyces cerevisiae as a probiotic at level of $0.5 \mathrm{~g} / \mathrm{kg}$ DM feed compared to un-supplemented group being values were 3.8 vs $3.9 \mathrm{~L} / \mathrm{lamb} /$ day, respectively.

\section{Table 11 - Water utilization as affected by feeding ewes on different roughages and dry yeast}

\begin{tabular}{|c|c|c|c|c|c|c|c|c|c|}
\hline \multirow{2}{*}{\multicolumn{2}{|c|}{ Treatment }} & \multicolumn{2}{|c|}{ Free WI } & \multirow{2}{*}{$\begin{array}{l}\text { Feed WI } \\
\mathbf{g} / \mathbf{k g}^{0.82}\end{array}$} & \multirow{2}{*}{$\begin{array}{c}\text { TWI } \\
\text { g/kg0.82 }\end{array}$} & \multirow{2}{*}{$\begin{array}{c}\text { Feces water, } \\
\text { g/ kg0.82 }\end{array}$} & \multirow{2}{*}{$\begin{array}{l}\text { Urine water, } \\
\text { g/ kg0.82 }\end{array}$} & \multicolumn{2}{|c|}{ Insensible water loss; IWL } \\
\hline & & g/ $/ \mathbf{k g}^{0.82}$ & $\begin{array}{c}\% \text { of ash } \\
\text { intake }\end{array}$ & & & & & $\mathrm{g} / \mathrm{kg}^{0.82}$ & $\%$ of TWI \\
\hline \multirow{3}{*}{$\mathbf{R}$} & $\mathrm{BH}$ & $204^{a}$ & $38.4^{a}$ & $11.46^{b}$ & $236^{a}$ & $38.6^{a}$ & $69.8^{\mathrm{ab}}$ & $128^{a}$ & $54.07^{b}$ \\
\hline & FA & $145^{b}$ & $35.4^{\mathrm{ab}}$ & $45.93^{a}$ & $207^{a}$ & $16.9^{c}$ & $58.5^{b}$ & $132^{\mathrm{a}}$ & $63.57^{a}$ \\
\hline & AS & $146^{b}$ & $32.8^{b}$ & $49.16^{a}$ & $213^{a}$ & $28.9^{b}$ & $70.4^{a}$ & $114^{a}$ & $53.38^{b}$ \\
\hline \multirow{2}{*}{$\mathbf{Y}$} & $\mathbf{Y}^{-}$ & $120^{b}$ & $25.5^{b}$ & $30.86^{b}$ & $167^{b}$ & $26.6^{a}$ & $65.0^{a}$ & $75.4^{b}$ & $45.15^{b}$ \\
\hline & $\mathbf{Y}^{+}$ & $210^{a}$ & $45.6^{a}$ & $40.18^{a}$ & $269 a$ & $29.7^{a}$ & $67.4^{a}$ & $172^{a}$ & $63.90^{a}$ \\
\hline \multirow{6}{*}{$\mathbf{R} * \mathbf{Y}$} & BHY- & $181^{a}$ & $36.0^{b}$ & $10.80^{c}$ & $210^{b}$ & $33.6^{\mathrm{ab}}$ & $62.7^{a b}$ & $114^{\text {bc }}$ & $54.14^{b}$ \\
\hline & $\mathrm{BHY}^{+}$ & $227^{a}$ & $40.8^{\mathrm{ab}}$ & $12.13^{c}$ & $262^{a b}$ & $43.5^{a}$ & $76.8^{a}$ & $142^{\mathrm{ab}}$ & $54.08^{b}$ \\
\hline & FAY- & $93.3^{b}$ & $23.9^{c}$ & $37.23^{b}$ & $145^{c}$ & $18.0^{\mathrm{cd}}$ & $54.6^{b}$ & $72.4^{\mathrm{cd}}$ & $49.93^{b}$ \\
\hline & $\mathrm{FAY}^{+}$ & $197^{a}$ & $46.9^{a}$ & $54.63^{a}$ & $268^{a b}$ & $15.9^{d}$ & $62.4^{\mathrm{ab}}$ & $190^{a}$ & $70.78^{a}$ \\
\hline & ASY- & $86.8^{b}$ & $16.6^{c}$ & $44.55^{b}$ & $147^{c}$ & $28.1^{b c}$ & $77.8^{a}$ & $41.1^{d}$ & $27.96^{c}$ \\
\hline & $\mathrm{ASY}^{+}$ & $206^{a}$ & $49.0^{a}$ & $53.78^{a}$ & $278^{a}$ & $29.8^{b}$ & $62.9 \mathrm{ab}$ & $185^{a}$ & $66.65^{a}$ \\
\hline
\end{tabular}

\section{Rumen fermentation and blood biochemical parameters}

The parameters of rumen activity ( $\mathrm{pH}, \mathrm{VFA}$ and $\left.\mathrm{NH}_{3}-\mathrm{N}\right)$ as affected by the experimental rations are shown in Table 12. It is of interest to notice that $\mathrm{AS}$ ration showed higher rumen $\mathrm{pH}(6.04)$ compared to $\mathrm{FA}(5.74)$ and $\mathrm{BH}(5.55)$ rations. These findings may be attributed to slow degradation of OM that matched with the fermented OM in the rumen as shown in Table 9. The highest pH the lowest total VFA, this is what can be observed in AS (the lowest VFA) and BH (the highest VFA) rations. The increases in VFA at $3 \mathrm{~h}$ post- feeding were associated with a decrease in rumen $\mathrm{pH}$. This in agreement with the findings of Taie et al. (2005) that the increase in TVFA concentration is paralleled the reduction in ruminal $\mathrm{pH}$. Staples et al. (1984) noted that the optimum pH value for rumen cellulolytic bacteria was ranged "between" 5.8-6.3. This range was almost similar to that obtained in our study.

High degradable protein was expected as ruminal $\mathrm{NH}_{3}-\mathrm{N}$ concentration $(\mathrm{mg} / \mathrm{dl})$ increased which was $24.4,21.5$ and 17.8 for animals fed $\mathrm{BH}, \mathrm{FA}$ and AS rations, respectively (Table 12). Rumen $\mathrm{NH}_{3}-\mathrm{N}$ concentrations with all the experimental diets were within the range figures; 5.0-20.61 mg/dl, that reported by Satter and Slyter (1974) and Mehrez et al. (2001), respectively, which would satisfy microbial needs for $\mathbf{N}$ and hence maximize the rate of fermentation of the experimental diet and maximize the microbial growth in the rumen. Ruminal $\mathrm{pH}$ and $\mathrm{NH}_{3}-\mathrm{N}$ were not affected ( $\left.\mathrm{P}>0.05\right)$ by dry yeast supplementation at $5 \mathrm{~g} /$ day (Table 12). However, total VFA decreased $(P<0.05)$ because of yeast supplementation. Atriplex silage without yeast (ASY) showed the highest value of rumen pH being 6.16 however; BHYwas the lowest one (5.49). The ruminal concentration of $\mathrm{NH}_{3}-\mathrm{N}$ and total VFA were significantly higher for $\mathrm{BHY}$ - group (30.4 $\mathrm{mg} / \mathrm{dl}$ and $16.8 \mathrm{meq} / \mathrm{dl}$, respectively) as compared to the other experimental groups. The role of yeast on rumen fermentation is to improve ammonia uptake and microbial protein production Miller-Webster et al. (2002). Moreover, Dawson et al. (1990) suggested that yeast enhances fiber digestion and increase the number of cellulolytic bacteria in the rumen. Also, Ahmed et al. (2015) concluded that improved ruminal fermentation in terms of VFA production was observed with group fed yeast supplemented $(15 \mathrm{mmol} / \mathrm{dl})$ diet compared to hay group (13 mmol/dl). This suggests that the fermentation of diets supplemented with yeast $(0.5 \mathrm{~g} / \mathrm{kg} \mathrm{DM})$ was more efficient and produced more VFA than in the control diet, however, $\mathrm{NH}_{3}-\mathrm{N}$ was not affected and its corresponding values were 138, and $114 \mathrm{mg} / \mathrm{dl}$, respectively. Ben Salem et al. (2010) concluded that supplementing sheep with barley at $30 \%$ level increased fermentation in the rumen of sheep fed on Atriplex and enhanced utilization of degradable CP available in the rumen. In a comparison with the present 
data, Khattab (2007) concluded that $\mathrm{pH}$ at $3 \mathrm{~h}$ post-feeding was not affected $(\mathrm{P}>0.05)$ by the experimental roughages and the values were 5.83, 6.49 and 5.97 for hay and fresh or silage respectively. However, the highest values of $\mathrm{NH}_{3}-\mathrm{N}$ and VFA were observed in hay group $(31.09 \mathrm{mg} / \mathrm{dl}$ and $20.54 \mathrm{m.eq} / \mathrm{dl})$ as compared with groups of silage $(21.57 \mathrm{mg} / \mathrm{dl}$ and $13.65 \mathrm{m.eq} / \mathrm{dl})$ or fresh saltbush $(16.55 \mathrm{mg} / \mathrm{dl}$ and $11.53 \mathrm{m.eq} / \mathrm{dl})$. The author concluded that ruminal $\mathrm{NH}_{3}-\mathrm{N}$ concentration was positively correlated to CP or NPN contents in the ration as well as high CP degradability in the rumen.

Table 12 - Rumen fermentation indicators and blood biochemical parameters in Barki ewes fed different roughages and dry yeast.

\begin{tabular}{|c|c|c|c|c|c|c|c|c|c|c|c|}
\hline \multirow{2}{*}{ Item } & \multicolumn{3}{|c|}{ Roughage (R) } & \multicolumn{2}{|c|}{ Yeast (Y) } & \multicolumn{6}{|c|}{$\mathbf{R} * \mathbf{Y}$} \\
\hline & BH & FA & AS & $\mathbf{Y}$ & $\mathbf{Y}^{+}$ & BHY- & $\mathrm{BHY}^{+}$ & FAY- & FAY' $^{+}$ & ASY- & ASY+ $^{+}$ \\
\hline \multicolumn{12}{|c|}{ Rumen fermentation indicators at $3 \mathrm{~h}$ post-feeding } \\
\hline $\mathrm{pH}$ & $5.55^{b}$ & $5.74^{a b}$ & $6.04^{a}$ & $5.77^{a}$ & $5.78^{a}$ & $5.49^{b}$ & $5.60^{a b}$ & $5.66^{a b}$ & $5.82^{\mathrm{ab}}$ & $6.16^{a}$ & $5.93^{a b}$ \\
\hline VFA, meq/dl & $13.6^{a}$ & $10.7^{b}$ & $10.1^{b}$ & $14.1^{\mathrm{a}}$ & $8.86^{b}$ & $16.8^{a}$ & $10.3^{b c}$ & $12.9^{b}$ & $8.50^{c}$ & $12.5^{b}$ & $7.73^{c}$ \\
\hline $\mathrm{NH}_{3}-\mathrm{N}, \mathrm{mg} / \mathrm{dl}$ & $24.4^{a}$ & $21.5^{a b}$ & $17.8^{b}$ & $23.1^{\mathrm{a}}$ & $19.3^{a}$ & $30.4^{a}$ & $18.4^{\mathrm{bc}}$ & $24.4^{\mathrm{ab}}$ & $18.6^{\mathrm{bc}}$ & $14.7^{c}$ & $20.8^{b c}$ \\
\hline \multicolumn{12}{|c|}{ Blood biochemical parameters at zero-time post-feeding } \\
\hline Glu, mg/dl & $60.6^{a}$ & $72.2^{a}$ & $63.7^{a}$ & $59.5^{b}$ & $71.6^{a}$ & $58.0^{a b}$ & $63.2^{\mathrm{ab}}$ & $67.6^{\mathrm{ab}}$ & $76.8^{a}$ & $52.8^{b}$ & $74.7^{a}$ \\
\hline$T P, g / d l$ & $10.0^{a}$ & $7.80^{b}$ & $8.33^{a b}$ & $7.25^{b}$ & $10.2^{a}$ & $7.87^{b}$ & $12.2^{a}$ & $7.01^{b}$ & $8.60^{a b}$ & $6.87^{b}$ & $9.78^{\mathrm{ab}}$ \\
\hline Alb, g/dl & $3.31^{\mathrm{a}}$ & $3.23^{a}$ & $3.29 a$ & $3.36 \mathrm{a}$ & $3.19 a$ & $3.26^{a}$ & $3.35^{a}$ & $3.47^{a}$ & $2.99^{a}$ & $3.35^{a}$ & $3.24^{a}$ \\
\hline Glo, g/d & $6.69^{a}$ & $4.57^{b}$ & $5.04^{\mathrm{ab}}$ & $3.89^{b}$ & $7.01^{a}$ & $4.61^{b}$ & $8.85^{a}$ & $3.54^{b}$ & $5.61^{\mathrm{ab}}$ & $3.52^{b}$ & $6.54^{\mathrm{ab}}$ \\
\hline Urea, mmol/l & 7.04ab & $5.85^{b}$ & $8.46^{a}$ & $6.02^{b}$ & $8.22^{a}$ & $5.99^{b}$ & $8.09^{b}$ & $6.09^{b}$ & $5.61^{b}$ & $5.99^{b}$ & $10.9^{a}$ \\
\hline $\mathrm{Cr}, \mathrm{mg} / \mathrm{dl}$ & $1.55^{b}$ & $2.07^{a}$ & $2.20^{a}$ & $1.91^{a}$ & $1.97^{a}$ & $1.57^{b c}$ & $1.53 c$ & $2.02 \mathrm{abc}$ & $2.12^{\mathrm{abc}}$ & $2.15^{a b}$ & $2.25^{a}$ \\
\hline $\mathrm{CC}, \mathrm{ml} / \mathrm{min}$ & $18.4^{a}$ & $15.7^{b}$ & $18.2^{\mathrm{a}}$ & $18.8^{a}$ & $16.0^{b}$ & $20.3^{a}$ & $16.5^{b}$ & $16.1^{b}$ & $15.3^{b}$ & $20.1^{a}$ & $16.3^{b}$ \\
\hline $\mathrm{CC}, \mathrm{ml} / \mathrm{min} / \mathrm{kg}$ & $0.46^{a}$ & $0.39^{b}$ & $0.44^{a}$ & $0.47^{a}$ & $0.38^{b}$ & $0.51^{a}$ & $0.41^{b}$ & $0.41^{b}$ & $0.36^{b}$ & $0.51^{a}$ & $0.38^{b}$ \\
\hline
\end{tabular}

Blood biochemical parameters of the experimental groups are given in Table 12. Blood glucose (Glu) was not affected $(\mathrm{P}<0.05)$ by the types of roughage and the values ranged between 60.6 and $72.2 \mathrm{mg} / \mathrm{dl}$. However, the present results differ from those obtained by Khattab (2007) and Shawket et al. (2015) who reported that feeding halophytic plant silage increased $(P<0.05)$ the concentration of plasma glucose in Barki sheep than that fed fresh plants or control diets. Similarly, EL-Saadany et al. (2016) reported that plasma glucose increased significantly $(P<0.05)$ by feeding ewes on Atriplex plants compared with those fed hay. On the other hand, yeast addition increased $(P<0.05)$ Glu concentration by about $19.7 \%$ over than un-supplemented group. In addition, Glu was affected $(P<0.05)$ by the interaction $R * Y$ and high values were observed in two treatments; $\mathrm{FAY}^{+}(76.8 \mathrm{mg} / \mathrm{dl})$ and $\mathrm{ASY}^{+}(74.7 \mathrm{mg} / \mathrm{dl})$ but the lowest observed only in $\mathrm{ASY}_{-}$ $(52.8 \mathrm{mg} / \mathrm{dl})$. Higher glucose concentrations in ewes fed a yeast-supplemented diet, observed in the present study, are consistent with the findings of Abdel-Gawad (2012) and Milewski and Sobiech (2009). They demonstrated that dry yeast (S cerevisiae) significantly increased the production of propionic acid - the main substrate for glucose synthesis in ruminants. Higher serum glucose resulted by dried yeast supplementation could be related to elevated concentrations of mannan-oligosaccharides are precursors of VFA, which affect an increase in energy metabolism parameters.

Because of blood albumin (Alb) concentration was not affected by the types of roughage, yeast addition and their interaction, the total protein (TP) and globulin (Glo) concentrations showed the same significance pattern (Table 12). The highest values of both parameters were observed in $\mathrm{BH}, \mathrm{Y}^{+}$and $\mathrm{BHY}^{+}$for $\mathrm{R}, \mathrm{Y}$ and $\mathrm{R}^{*} \mathrm{Y}$ treatments, respectively. The noneyeast supplemented group $\left(Y^{-}\right)$recorded higher $C C(0.47 \mathrm{ml} / \mathrm{min} / \mathrm{kg})$ than the supplemented one $\left(\mathrm{Y}^{+}\right)(0.38 \mathrm{ml} / \mathrm{min} / \mathrm{kg})$. Also, BHY- and ASY- recorded similar and highest value $(0.51 \mathrm{ml} / \mathrm{min} / \mathrm{kg})$ compared to the other interaction groups. The present data were in contrasting with that reported by Khattab (2007), Fayed et al. (2010), Shawket et al. (2015) and ElGohary et al. (2017) who found no significant differences between fresh or silage Atriplex and hay groups concerning blood total protein. However, feeding fresh Atriplex significantly increased albumin concentration (El-Gohary et al., 2017) but decreased $(P<0.05)$ the globulin concentration (Khattab (2007). Abdel-Gawad (2012) indicated that yeast supplemented groups had significantly higher serum total protein and globulin than the control group.

Urea and creatinine are the two chief nitrogenous composites excreted by kidney. Thus, any change of their concentration would reflect impaired glomerular filtration and/or inefficiency of renal tubules (Braun and Lefebvre 2008). The animal groups received $\mathrm{AS}, \mathrm{Y}^{+}$and $\mathrm{ASY}^{+}$rations recorded the highest concentration (ummol/I) of blood urea versus that recorded the lowest values in groups of FA, $Y^{-}$and all the other groups within interaction treatments (Table 12). The present results come in the same direction with those obtained by Shawket et al. (2015) who reported that Barki ewes fed control and silage diets showed higher $(P<0.05)$ blood urea concentration when compared with those fed fresh foliage diet. This may be due to the high content of anti-nutritional factors in fresh forage which binding with feed proteins and reduce its utilization (Ndluvo, 2000). On the other hand, there is fluctuation results regarding the blood urea concentration of sheep in different studies (Khattab, 2007; Fayed et al., 2010 and El-Saadany et al., 2016), these may be due to differ in feed concentrate that used in each study. The increase in urea concentration recorded in this study owing to yeast addition suggests that yeast had an effect on renal function (Milewski and Sobiech, 2009 and Abdel-Gawad, 2012). 
There were significant effects due to roughage types, yeast addition and their interaction on blood creatinine concentration (Table 12). High creatinine value in FA and AS groups compared to BH was observed also by Shawket et al. (2015) and these findings may be attributed to high anti-nutritional factors and/or high salt contents in these diets. The renal endogenous creatinine clearance (CC; an index of glomerular filtration rate) was expressed as $\mathrm{ml} / \mathrm{min}$ or $\mathrm{ml} / \mathrm{min} / \mathrm{kg}$. The renal clearance of endogenous creatinine was $0.0 .64,0.44$ and $39 \mathrm{ml} / \mathrm{min} . \mathrm{kg}$ for BH, AS and FA groups, respectively (Table 12). It can be said that FA, $\mathrm{Y}^{+}, \mathrm{SAY}^{+}, \mathrm{FAY}^{+}, \mathrm{FAY}$ - and $\mathrm{BHY}^{+}$caused partial renal damage or alterations in glomerular function that affect the kidneys' ability to remove metabolic substances from the blood into the urine. The overall mean value of renal clearance of endogenous creatinine recorded herein was $0.43 \mathrm{ml} / \mathrm{min} . \mathrm{kg}$, that is lower than that previously reported by Javed et al. (2006) for sheep being $0.81 \mathrm{ml} / \mathrm{min} . \mathrm{kg}$. In addition, Chen et al. (1995) concluded that creatinine clearance was not affected $(P>0.05)$ by DM intake in sheep.

\title{
CONCLUSION
}

- Silage roughage represents about $57.7-60.6 \%$ of the total food intake during pregnancy and lactation periods, respectively which reduces the cost of the ration compared to Berseem hay. It also covers the dry matter, energy and protein required during pregnancy and lactation to a better degree than fresh Atriplex forage. Yeast addition reduced the total intake during early and late pregnancy periods by $3.60-5.32 \%$, respectively compared to that without yeast.

- No significant difference was observed between AS and BH in the production of energy corrected milk ECM, as well as the energy content of milk in the form of $\mathrm{Kcal} / \mathrm{kg}$. Addition of yeast led to a significant improvement for the production of energy-corrected milk ECM by $7.84 \%$ compared to no addition. Yeast improved ECM by $10.6,23.8$ and $5.52 \%$ when added to $\mathrm{BH}, \mathrm{FA}$ and $\mathrm{AS}$ diets, respectively as compared to those roughages without yeast.

- Under the same experimental conditions, weaning weight as a final index of the productive efficiency of ewes as

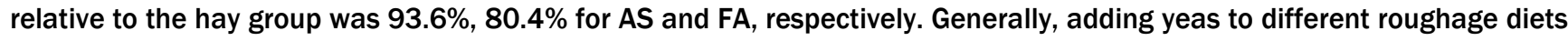
during suckling period led to an increase in weaning weight by $11.1 \%$ compared to those without yeast. Yeast added to $\mathrm{BH}, \mathrm{FA}$ and SA diets improved weaning weight by $9.93,10.05$ and $13.27 \%$, respectively compared with those without yeast.

- The economic efficiency (EE) was higher in both FA and AS compared to BH. The yeast addition $\left(\mathrm{Y}^{+}\right)$resulted significantly higher EE compared to $\mathrm{Y}$. The EE was enhanced by adding yeast to $\mathrm{BH}, \mathrm{AS}$ and FA diets with $0.48,0.33$ and 0.03 compared with those without yeast.

\section{DECLARATIONS}

\author{
Corresponding Author \\ E-mail: kewandrc@yahoo.com
}

Authors' Contribution

Khalid Zein-Alabdein Kewan contributes on data analysis and the write up of the manuscript and approved the final manuscript.

Conflict of interests

The authors have not declared any conflict of interests.

\section{REFERENCES}

Abd El-Rahman HH, Mohamed MI, Gehad AEA and Awadallah IM (2004). Ameliorating the anti-nutritional factors effect in Atriplex halimus on sheep and goats by ensiling or Polyethelene glycol supplementation. Egyptian Journal of Animal Production, 41 (Supplement Issue): 275282. https://journals.ekb.eg/article_108350_ac47375421ded08ebbfbba903ef41d58.pdf

Abdel-Gawad AM (2012). Effect of dietary lacture yeast supplement on productive performance of Egyptian Rahmani ewes and their lambs. Journal of Animal and Poultry Production Mansoura University, 3 (5): 215 - 226. DOI: http//www.doi.org/10.21608/jappmu.2012.82789

Abou'I Ella AA (2007). Effect of dry yeast and/or bentonits as feed additives on the productive performance of lactating ewes and its offspring's. Egyptian Journal of Nutrition 10 and 1 : https://scholar.google.com/scholar?cluster=12323949258722887467\&hl=en\&as sdt=2005\&sciodt=0,5

Abu-Zanat MMW and Tabbaa MJ (2006). Effect of feeding Atriplex browse to lactating ewes on milk yield and growth rate of their lambs. Small Ruminant Research, 64 (1): 152-161. http//www.doi.org/10.1016/j.smallrumres.2005.04.004

Abu-Zanat MMW, Al-Hassanat FM, Alawi M and Ruyle GB (2003). Oxalate and tannins assessment in Atriplex halimus L. and A. nummularia L. Journal of Range Management, 56 (4): 370-374. https://journals.uair.arizona.edu/index.php/jrm/article/viewFile/9816/9428

Ahmed MH, Elghandour MMY, Salem AZM, Zeweil HS, Kholif AE, Klieve AV and Abdelrassol AMA (2015). Influence of Trichoderma reesei or Saccharomyces cerevisiae on performance, ruminal fermentation, carcass characteristicsa nd blood biochemistry of lambs fed Atriplex nummularia and Acacia saligna mixture. Livestock Science, 180: 90-97. http//www.doi.org/10.1016/j.livsci.2015.06.019

Alhanafi F, Kaysi Y, Muna M, Alkhtib A, Wamatu J and Burton E (2019). Spineless cactus (Opuntia ficus-indica) and saltbush (Atriplex halimus L.) as feed supplements for fattening Awassi male lambs: effect on digestibility, water consumption, blood metabolites, and growth performance. Tropical Animal Health and Production, 51(6): 1637-1644. http//www.doi.org/10.1007/s11250-019-01858-6

Allam AM, Elshegly K, Borhami BEA and Mohamed MA (2001). Effect of Baker's Yeast (Sacchromyces Cerevisiae) Supplementation on digestion in sleep and milk response in dairy Cows. Egyptian Journal of Nutrition and Feeds, 4 (special Issue): $315-323$. https://www.cabdirect.org/cabdirect/abstract/20003028439 
Alshaikh MA, Alsiadi MY, Zahran SM, Mogawer HH and Aalshowime TA (2002). Effect of feeding yeast culture from different sources on the performance of lactating Holstein cows in Saudi Arabia. Asian-Australasian Journal of Animal Science, 15(3): 352-356. http//www.doi.org/10.5713/ajas.2002.352

AOAC (1984). Official methods of analysis. 14th ed. Assoc. Off. Analysis Chemistry, Arlington, VA.

AOAC (1997). Association of Official Analytical Chemists, Official Methods of Analysis, 16th ed. AOAC, Arlington, VA, USA.

AOAC. (2005). Official methods of analysis, 18th ed. Association of Official Analytical Chemists, Washington, D.C. Accessed 4/25/16.

Askar AR, Nassar MS, Badawy HS, Eid EY, Guada JA and Farid MFA (2016). Recovered energy and efficiency of digestion in sheep and goats fed Atriplex nummularia compared to alfalfa hay. Livestock Science, 194: 1-6. Doi.org/10.1016/j.livsci.2016.10.009

Attia Marwa FA, Nasser MEA, Zeitoun MM, El-Gendy MN, El-Shazly KA and Sallam SMA (2018). Digestion of tanniniferous plants in ruminants. In vitro ruminal and post-ruminal protein digestion of some Egyptian tanniniferous plants. Journal of Food, Agriculture and Environment, 16 (2):100-107. https://www.wflpublisher.com/Abstract/5504

Baiomy AA (2011). Influence of live yeast culture on milk production, composition and some metabolities of Ossimi ewes during the milking period. American Journal of Molecular Biology, 1 (2), 158-167. http//www.doi.org/10.21608/jappmu.2010.86260

Baldi A, Cheli F, Corino C, Dell'Orto V and Polidroi F (1992). Effects of feeding calcium salts of long chain fatty acids on milk yield, milk composition and plasma parameters of lactating goats. Small Ruminant Research, 6(4): 303-310. http//www.doi.org/10.1016/09214488(91)90137-F

Ben Salem H, Nefzaoui A and Ben Salem L (2002). Supplementation of Acacia cyanophylla Lindi. Foliage-based diets with barley or shrubs from arid areas (Opuntia ficus-indica $f$. inermis and Atriplex nummularia L.) on growth and digestibility in lambs. Animal Feed Science and Technology, 96(1-2): 15-30. http//www.doi.org/10.1016/S0377-8401(01)00338-8

Ben Salem H, Normanb HC, Nefzaouic A, Mayberryb DE, Pearced KL and Revellb DK (2010). Potential use of oldman saltbush (Atriplex nummularia Lindl.) in sheep and goat feeding. Small Ruminant Research 91 (1): 13-28. http//www.doi.org/10.1016/j.smallrumres.2009.10.017

Bernard JK (1997). Milk production and composition responses to the source of protein supplements in diets containing wheat middlings. Journal of Dairy Science, 80 (5): 938-942. http//www.doi.org/10.3168/jds.S0022-0302(97)76017-X

Bonavia N and McGregor BA (2021). Digestion, faecal grain loss and energy requirements of Huacaya alpacas fed lucerne chaff, oat chaff and whole grain barley diets. Small Ruminant Research, 2021: 106444. http//www.doi.org/10.1016/j.smallrumres.2021.106444

Braun JP and Lefebvre HP (2008) Kidney Function and Damage. In: JJ Kaneko, JW Harvey and ML Bruss(Editors). Clinical Biochemistry of Domestic Animals. Chapter 16, P485-528. Animals.6 ${ }^{\text {th }}$ Edit. Elsevier/Academic Press, Burlington, MA, Amsterdam. http//www.doi.org/ 10.1016/B978-0-12-370491-7.X0001-3

Chen X. B, Mejia, AT, Kyle DJ and Ørskov ER (1995). Evaluation of the use of purine derivative:creatinine ratio in spot urine and plasma samples as an index of microbial protein supply in ruminants: Studies in sheep. Journal of Agricultural Science, 125 (1):137-143. http//www.doi.org/10.1017/S002185960007458X

CLFF (2001). Central lab for food and feed. Food composition tables for animal and poultry feedstuffs used in Egypt. Technical bulletin No. 1 (2001), 22 pages.

Dawson KA, Newman KE and Boling JA (1990). Effects of microbial supplements containing yeast and lactobacilli on roughage-fed ruminal microbial activities. Journal of Animal Science, 60 (10): 3392-3398. http//www.doi.org/10.2527/1990.68103392x

de Araújo GG, Santos GA, Voltolini TV, de Moraes SA, Pereira LG, Gois GC, and Campos FS (2018). Chemical composition and fermentative characteristics of old man saltbush silage supplemented with energy concentrates. Embrapa Semiárido-Artigo em Periódico Indexado (ALICE), 39 (3): 1155-1166. http//www.doi.org/10.5433/1679-0359.2018v39n3p1155

Elaref MY, Hamdon HAM, Nayel UA, Salem AZM and Anele UY (2020). Influence of dietary supplementation of yeast on milk composition and lactation curve behavior of Sohagi ewes, and the growth performance of their newborn lambs. Small Ruminant Research, $191: 106176$. http//www.doi.org/10.1016/j.smallrumres.2020.106176

EL-Gohary ESH, Fathala MM, El-Rayes M. A-H, Abou-Aiana RM and Eissa MM (2017). Effect of using tanniniferous plants shrubs in feeding Barki ewes on some productive and physiological parameters. Journal of Animal and Poultry Production Mansoura University, 8 (12): $467-476$. http//www.doi.org/10.21608/JAPPMU.2017.46065

EL-Saadany SA and Omar HH (2018). Effect of feeding Barki Ewes by halophytic plants on the gross chemical composition, elements content and anti- oxidants compounds. Journal of Food and Dairy Science Mansoura University, 9 (12): 403-409. http//www.doi.org/10.21608/JFDS.2018.36104

EL-Saadany SA, EL-Gohary ESH, Omar HH, EL-wakeel EL and EL-sayed IA (2016). Impact of feeding some forage shrubs on milk, blood parameters of ewes and growth performance of their offsprings in Northern Coast. Journal of Animal and Poultry Production Mansoura University, 7 (1): 47- 57. http//www.doi.org/10.21608/JAPPMU.2016.48270

EI Shaer HM and Gihad EA (1994). Halophytes as animal feeds in Egyptian deserts. In Halophytes as a Resource for Livestock and for Rehabilitation of Degraded Lands; Squires, V.R., Ayoub, A.T., Eds.; Springer Netherlands: Dordrecht, The Netherlands, 1994; pp. 281-284, ISBN 978-94-011-0818-8. D0I:10.1007/978-94-011-0818-8_28

Farid MFA, Khamis HS, Eid EYA, Abdou Alam R and Helal A (2005). Feeding management and the performance of sheep in Southern Sinai: 3. The lambs pre- and post-weaning. Journal of Agricultural Sciences Mansoura University, 30 (12): 7477-7494.

Fayed Afaf M, El- Essawy Abeer M, Eid EY, Helal HG, Abdou Ahlam R and El Shaer HM (2010). Utilization of alfalfa and atriplex for feeding sheep under saline conditions of South Sinai, Egypt. Journal of American Science, 6 (12): 1447-1461. http//www.doi.org/10.7537/marsjas061210.161

Habeeb AAM (2017). Importance of yeast in ruminants feeding on production and reproduction. Ecology and Evolutionary Biology, 2(4): 49-58. Doi: 10.11648/j.eeb.20170204.11

Javed I, Rahman ZU, Khan FH, Muhammad F, Iqbal Z and Aslam B (2006). Renal clearance and urinary excretion of kanamycin in domestic ruminant species. Pakistan Veterinary Journal, 26(1): 1-8. Link, https://www.researchgate.net/profile/Zia-Rahman16/publication/26520670

Kearl IC (1982). Nutrients requirements in developing countries. Utah Agric. Exp. Stat., Utah State University, Logan, USA. https://scholar.google.com/scholar?hl=en\&as_sdt=0\%2C5\&q=Kearl+IC+\%281982\%29.+Nutrients+requirements+in+developing+countr ies.+Utah+Agric.+Exp.+Stat.\%2C+Utah+State+University\%2C+Logan\%2C+USA.\&btnG=

Kewan KZ (2013). Nutritional response of agro-industrial by-products as replacements of concentrate feed mixture in sheep diets. Egyptian Journal of Nutrition and Feeds, 16(1):93-102. https://www.researchgate.net/publication/352569427_Nutritional_response_of_agroindustrial_by-products_as_replacements_of_concentrate_feed_mixture_in_sheep_diets.

Kewan KZ, Abo Bakr S, Nassar MS, El-Shereef Afaf M and El-Rayes MA-H (2021a). Utilization of trimming waste of mandarin trees as feed for small ruminants: 2- Evaluation of Barki ewes performance during suckling period. Animal Science Reporter, 14(2):1-27. Link: https://www.animalsciencereporter.com/ASRE-142-Text.pdf 
Kewan KZ, Ali MM, Ahmed BM, El-Kolty Sara A, Nayel UA (2021b). The effect of yeast (Saccharomyces cerevisae), garlic (Allium sativum) and their combination as feed additives in finishing diets on the performance, ruminal fermentation, and immune status of lambs. Egyptian Journal of Nutrition and Feeds, 24(1): 55-76. http//www.doi.org/ 10.21608/EJNF.2021.170304

Kewan KZ, El-Essawy, Abeer M, Shawket Safinaz M and El Shaer HM (2009). Effects of energy sources supplement for camels fed berseem hay on: 1. Feed intake, nutrients digestibility and concentration of some blood constituents. Journal of Agricultural Sciences Mansoura University, 34 (4): 2803 - 2817. http//www.doi.org/10.21608/JAPPMU.2009.116929

Kewan KZ, Elkhouly AA, Negm AM and Javadi A (2019). Feedstock values of some common fodder halophytes in the Egyptian desert. TwentySecond International Water Technology Conference, IWTC22 Ismailia, Egypt, 12-13 September 2019, $P$ 382-401. http://iwtc2019.website2.me/upload/661292/documents/779FA106B0226B6A.pdf

Khattab IAM (2007). Studies on halophytic forages as sheep fodder under arid and semi arid conditions in Egypt, PhD Thesis, Faculty of Agriculture, Alexandria University, Egypt. PP 74. https://www.academia.edu/download/38830859/2007._Khattab_phD.pdf

Maamouri $O$ and Ben Salem (2021). Effect of yeast culture feed supply on growth, ruminal pH, and digestibility of fattening calves. Food Science and Nutrition, 9(5): 2762- 2767. https://doi.org/10.1002/fsn3.2238

Masek T, Mikulec Ž, Valpotic H, Kušće L, Antunac N and Antunac N (2008). The influence of live yeast cells (Saccharomyces Cerevisiae) on the performance of grazing dairy sheep in late lactation. Veterinarski arhiv, 78 (2): 95-104. Link: http://wwwi.vef.hr/vetarhiv/index.php?p1=li\&p2=2008\&p3=78\&p4=2\&p5=0

Mehrez AZ, Soliman EM, El-Ayek MY, El Ayouty EA and EI Kholany ME (2001). Influence of roughage to concentrate ratio and type of roughage on digestibility, some rumen parameters and fiber fractions degradability of treated rations with ruminants. Egyptian Journal of Nutrition

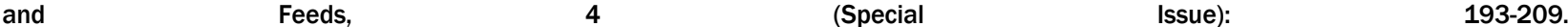
https://scholar.google.com/scholar?cluster=4585079933442742725\&hl=en\&as_sdt=2005\&sciodt=0,5

Merkel RC, Pond KR, Burns JC and Fisher DS (1999). Intake, digestibility and nitrogen utilization of three tropical tree legumes I. As sole feeds compared to Asystasia intrusa and Brachiaria brizantha. Animal Feed Science and Technology, 82 (1-2):91-106. Doi.org/10.1016/S03778401(99)00094-2

Milewski S and Sobiech P (2009). Effect of dietary supplementation with saccharomyces cerevisiae dried yeast on milk yield, blood biochemical and haematological indices in ewes. Bulletin of the Veterinary Institute Pulawy, 53 (4): 753-758. https://www.cabdirect.org/cabdirect/abstract/20103045663

Miller-Webster T, Hoover WH and Holt M (2002).Influence of yeast culture on ruminal microbial metabolism in continuous culture. Journal of Dairy Science, 85 (8): 2009-2014. http//www.doi.org/10.3168/jds.S0022-0302(02)74277-X

Mohammady MI, Hammam AH and Ibrahim NH (2014). Returns and economical efficiency of barki sheep fed on salt tolerant plants in Sinai, Egypt. Journal of American Science, 10 (4):134-139. http//www.doi.org/10.7537/marsjas100414.17

Morag M (1973). The definition of milk yield and milk fractions in lactating animals. Journal of Agricultural Science, Cambridge, 81(2), 361-363. http//www.doi.org/10.1017/S0021859600059037

Mousa KhM, El-Malky OM, Komonna OF and Rashwan SE (2012). Effect of live dried yeast supplementation on digestion coefficients, some rumen fermentation, blood constituents and some reproductive and productive parameters in Rahmani sheep. Journal of American Science 8(2), 291-303. Doi:10.7537/marsjas080212.42

Ndluvo LR (2000). Tannins in Animal agriculture: friend or foe. In: Proceeding of the South Africa Society of Animal Science Congress, 25-27 July 2000, pp. 51-52. https://scholar.google.com/scholar?cluster=9956433161282526581\&hl=en\&as sdt=2005\&sciodt=0,5

NRC (1985). Nutrient Requirements of Sheep. National Research Council, Washington, DC, USA.

Preston TR (1995). Biological and Chemical Analytical Methods. Tropical animal feeding: a manual for research workers. Rome: FAO (1995): 191-264. Link: http://www.fao.org/DOCREP/003/V9327E/V9327E00.HTM

Salama AAK, Caja G, Garin D, Albanell E, Such X, Casals R (2002).Effects of adding a mixture of malate and yeast culture (Saccharomyces cerevisiae) on milk production of Murciano-Granadina dairy goats. Animal Research, 51: 295-303. http//www.doi.org/10.1051/animres:2002025

Saleh HM, EL Ashry MA, Khorshed MM and Saleh Safaa A (2004). Performance of male lambs fed rations supplemented with active dried yeast. Egyptian Journal of Applied 1-12. https://scholar.google.com/scholar?cluster=18144914271672471895\&hl=en\&as_sdt=2005\&sciodt=0,5

SAS (2002). Institute. SAS/STAT User's Guide: Version 8.2. SAS Institute Inc., Cary, NC.

Satter LD and Slyter LL (1974). Effect of ammonia concentration on rumen microbial protein production in vitro. British Journal of Nutrition, 32(2): 199-208. http//www.doi.org/10.1079/BJN19740073

Shawket Safinaz M (1999a). Effect of energy level supplementation on the utilization of some pasture plants by goats. Journal of Agricultural $\begin{array}{llll}\text { Sciences University, 24: 4565-4573. } & \text { Mansoura }\end{array}$ https://scholar.google.com/scholar?cluster=870795894372614771\&hl=en\&as_sdt=2005\&sciodt=0,5

Shawket Safinaz M. (1999b). Fattening of Camel calves on saltbush (Atriplex halimus) with different energy sources. Journal of Agricultural
Sciences
Mansoura
University,
24
1751-1764.

Shawke Safinaz M, Khattab IM and Ahmed MH (2015). Impact of prolonged feeding halophytic plants on ewe's reproductive and productive performance. Egyptian Journal of Sheep \& Goat Sciences, Proceedings Book of the $5^{\text {th }}$ International Scientific Conference on Small Ruminant Production, Sharm El-Sheikh, Egypt, 2015, P: 3-17. http//www.doi.org/10.21608/ejsgs.2015.26641

Shurson GC (2018). Yeast and yeast derivatives in feed additives and ingredients: Sources, characteristics, animal responses, and quantification methods. Animal Feed Science and Technology, 235, 60-76. http//www.doi.org/10.1016/j.anifeedsci.2017.11.010

Solanas E, Castrillo C, Balcells J, Fondevila M and Guada JA (2003). Estimaci ó on de la digestibilidad intestinal de la prote ýna no degradada en rumen de diferentes suplementos proteicos mediante $\mathrm{m}^{-}$etodos in situ e in vitro. ITEA Journal - International Tuba Euphonium Association, 24(II):696-698. Link: https://www.aida-itea.org/aida-itea/files/jornadas/2003/comunicaciones/2003_NyA_36.pdf

Staples CR, Fernando RL, Fahey GC, Berger LL. and Jaster EH (1984). Effect of intake of a mixed diet by dairy steers on digestion events. Journal of Dairy Science, 67(5): 995. http//www.doi.org/10.3168/jds.S0022-0302(84)81398-3

Taie HT, Abdel Rahman KM and El-Sheikh Hanim A (2005). Digestibility, nitrogen balance and ruminal constituents of goats fed different clover hay levels. Egyptian Journal of Nutrition and Feeds, 8 (Special Issue): $325-335$. https://scholar.google.com/scholar?cluster=18437049583342289462\&hl=en\&as_sdt=2005\&sciodt=0,5

Zaleska B, Milewski S and Zabek K (2015). Impact of Saccharomyces cerevisiae supplementation on reproductive performance, milk yield in ewes and offspring growth. Archives Animal Breeding, 58: 79-83. http//www.doi.org/10.5194/aab-58-79-2015 